\title{
Equine Infectious Anemia Virus (EIAV): what has HIV's country cousin got to tell us?
}

\author{
Caroline LEROUX ${ }^{\mathrm{a} *}$, Jean-Luc CADORÉa, ${ }^{\mathrm{a}}$, Ronald C. MONTELARO ${ }^{\mathrm{c}}$ \\ a UMR754 INRA-UCBL-ENVL "Rétrovirus et Pathologie Comparée”, IFR128, Université Claude \\ Bernard Lyon I, 50 avenue Tony Garnier, 69007 Lyon, France \\ b Département Hippique, Médecine interne École Nationale Vétérinaire de Lyon, France \\ ${ }^{c}$ Department of Molecular Genetics and Biochemistry, Department of Infectious Diseases \\ and Microbiology, University of Pittsburgh, Pennsylvania, USA
}

(Received 16 December 2003; accepted 2 March 2004)

\begin{abstract}
Equine Infectious Anemia Virus (EIAV) is a lentivirus, of the Retrovirus family, with an almost worldwide distribution, infecting equids. It causes a persistent infection characterized by recurring febrile episodes associating viremia, fever, thrombocytopenia, and wasting symptoms. The disease is experimentally reproducible by inoculation of Shetland ponies or horses with EIAV pathogenic strains. Among lentiviruses, EIAV is unique in that, despite a rapid virus replication and antigenic variation, most animals progress from a chronic stage characterized by recurring peaks of viremia and fever to an asymptomatic stage of infection. The inapparent carriers remain infective for life, as demonstrated by experimental transfer of blood to naive animals. The understanding of the correlates of this immune control is of great interest in defining vaccine strategies. Research on EIAV, this "country cousin" of HIV (Human Immunodeficiency Virus), over the last five decades has produced some interesting results on natural immunological control of lentivirus replication and disease and on the nature and role of virus variation in persistence and pathogenesis. These studies are of interest in the context of HIV and efforts to develop a vaccine. This review will focus on some of the most recent results.
\end{abstract}

equine infectious anemia virus / lentivirus / equids / vaccine / viral evolution

Table of contents

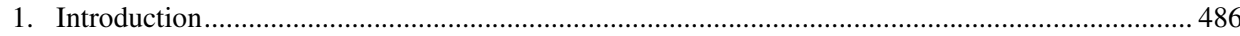

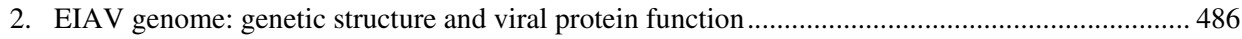

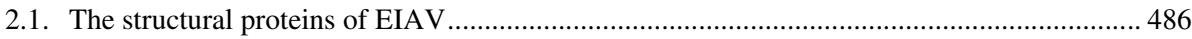

2.2. Function of the EIAV LTR (Long Terminal Repeat) ..............................................................48

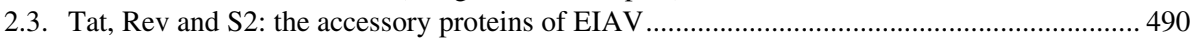

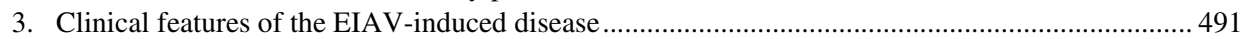

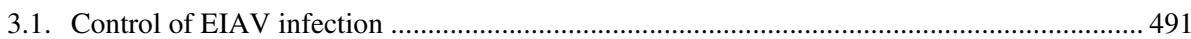

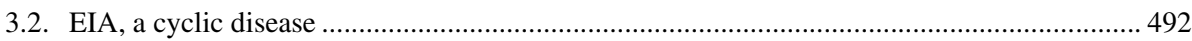

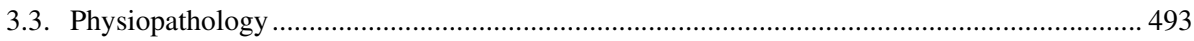

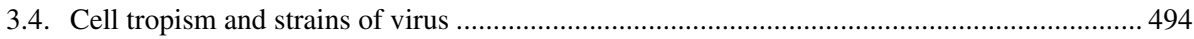

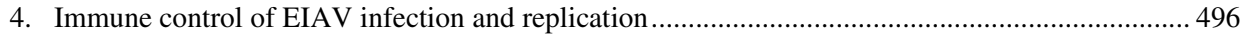

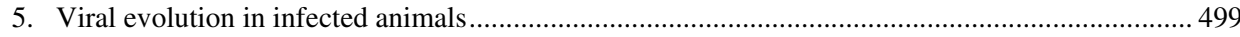

\footnotetext{
* Corresponding author: caroline.leroux@univ-lyon1.fr
} 
6. EIAV vaccine development. 502

7. Conclusion

\section{INTRODUCTION}

Equine Infectious Anemia Virus (EIAV) is an RNA virus, a member of the Retroviridae family and of the lentivirus genus [179], infecting equids. Equine Infectious Anemia (EIA) was first described in France in 1843 by Ligné [92] and was associated with infection with a "filterable agent" in 1904 [178]. This makes EIA the first animal disease to be assigned a viral etiology, preceding by several years the major discovery of the first tumor virus by Rous [149]. EIAV is mechanically transmitted by insect vectors $[40,41]$ or unsterile needles. The main route of transmission is by hematophagous insects of the Tabanidae family $[34,57,64]$. The virus is carried on the mouthparts of the horsefly. The receptor for EIAV on the cellular membrane remains unknown.

For years, knowledge of the molecular biology of EIAV has been retarded by the lack of a tissue culture system. Development of in vitro systems [99] and production of viral particles led to the classification of EIAV as a member of the Retroviridae family [18] and opened the possibility of biochemical and molecular studies.

Perhaps the most intriguing feature of EIAV infection is the ability of most animals eventually to control the viral replication. Unlike other retroviruses, long-term infection is associated with limited virus replication and the absence of clinical manifestations. The immune mechanisms responsible for this control may have considerable implications for vaccine design in other lentiviral infections.

\section{EIAV GENOME: GENETIC STRUCTURE AND VIRAL PROTEIN FUNCTION}

At $8.2 \mathrm{~kb}$, the EIAV RNA genome is the smallest and genetically simplest lentiviral genome. In addition to the structural pro- teins encoded by gag, pol and env, the EIAV genome contains three open reading frames encoding the Tat and Rev proteins generally present in lentiviruses and the S2 protein (Figs. 1A and 1B).

\subsection{The structural proteins of EIAV}

The gag and pol gene products are translated from the full-length viral messenger RNA [122]. Synthesis of Gag-Pol polyproteins requires ribosomes to shift their translational reading frame to read through the stop codon in gag. Several critical motifs including an AAA AAAC slippery sequence, a 5-base GC-paired segment downstream of the slippery sequence and a pseudoknot structure, affect EIAV Gag-Pol frameshifting [19]. The assembly of Gag precursor proteins on the plasma membrane is essential for virus budding from the host cells. The EIAV Gag-precursor (Pr55 ${ }^{\mathrm{gag}}$ ) polyprotein is cleaved by viral protease into four major internal structural proteins of the mature virion: the membrane-interacting matrix (MA) p15, the capsid (CA) p26, the RNA-binding nucleocapsid (NC) proteins p11 and p9 [62, 163] (Fig. 1A). After proteolytic processing of Gag, MA remains associated with the inner face of the viral membrane, and CA condenses to form a shell around the NC/RNA complex (for review [42]). The crystal structure of the matrix protein has recently been resolved [56]. Interestingly, despite the lack of sequence homology, there is a striking overall structure similarity with HIV-1 and SIV (Simian Immunodeficiency Virus) MA, except that it does not exhibit the same trimeric association [56]. The EIAV MA is compacted such that the $\mathrm{N}$ and $\mathrm{C}$ termini are in close proximity [56]. The Gag polyprotein drives assembly and budding of retroviruses and small regions, namely L (Late) domains, mediates its ability to bind to the cell membrane and induces the final step of 

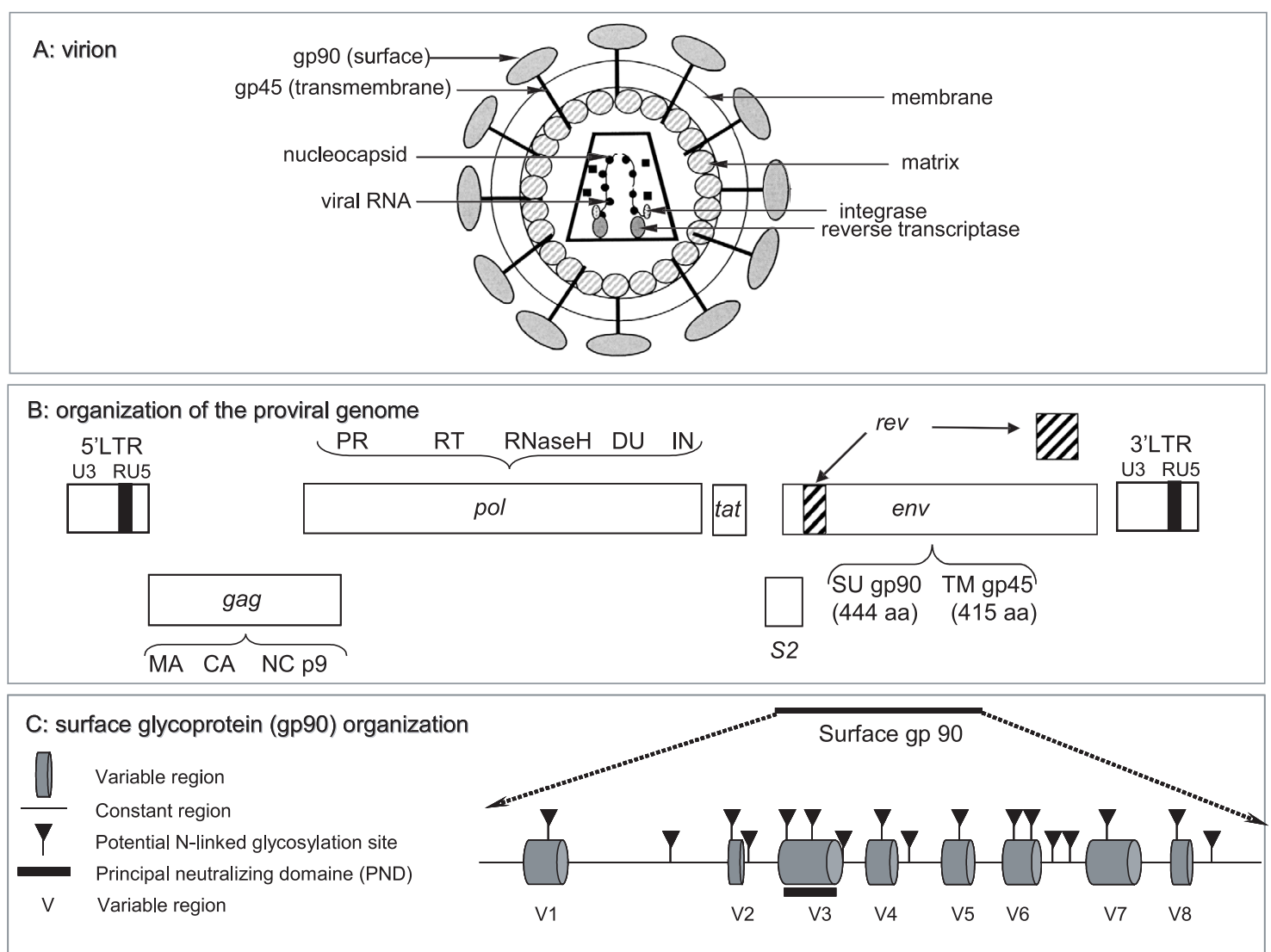

Figure 1. Schematic structure of the EIAV virion (A) and proviral genome (B). The detailed organization of the surface glycoprotein gp 90 is described (C) with the position of the variable regions. LTR: Long Terminal repeat; MA: matrix; CA: capsid; NC: nucleocapsid; PR: protease; RT: reverse transcriptase; DU: dUTPase; IN: integrase; SU: surface; TM: transmembrane. 
separation of the nascent viral particle (reviewed in [168]) (Fig. 2). EIAV P9 is the equivalent of P6 of HIV and P2b of RSV (Rous Sarcoma Virus), two proteins involved in particle budding from the cell [127]. Retroviral $\mathrm{L}$ domains have been mapped to 3 motifs PT/SAP, PPXY or YPXL (reviewed in [43]). EIAV is unique among the retroviruses studied to date because its $\mathrm{L}$ domain is a YPDL motif located in the C-terminus region of $\mathrm{P9}$ [135]. Budding of the virus from the host cell requires membrane fission. EIAV, like HIV or MoMLV (Moloney Murine Leukemia Virus), requires components of the cellular vacuolar protein sorting (VPS) machinery for efficient release [170, 182]. EIAV P9 interacts via its YPDL motif with the cellular AP2 clathrin-associated adapter protein complex [135, 136], but a definite role for AP2 in EIAV budding remains to be established. AIP1/ALIX, is a binding partner of EIAV p9 [101, 166]. Class E VPS proteins are involved in multivesicular body (MVB) biosynthesis [68, 182]. AIP1/ALIX, a mammalian orthologue of the yeast class E VPS protein Bro1, plays a key role in the MVB network by linking complexes acting in the early and late stages of the pathway. Two recent studies [166] suggest that AIP1/ALIX may couple HIV-1 P6 and EIAV P9 to the late-acting endosomal sorting complex ESCRT-III (Endosomal Sorting Complexes Required for Transport-III) [101, 166]. Interestingly, mutational analysis in the context of the infectious molecular clone EIAV $_{\mathrm{UK}}$ revealed that only the $\mathrm{N}$-terminal 31 amino acids of the total 51 residues are required to maintain replication in transfected cells and that p9 is not absolutely required for efficient budding in the context of proviral gene expression, suggesting that other EIAV proteins can mediate this function [20].

Cleavage of the EIAV Gag-Pol precursor $\left(\operatorname{Pr} 180^{\mathrm{gag}} / \mathrm{pol}\right)$ yields the pol gene products (Figs. 1A and 1B), which produce various enzymatic activities including the reverse transcriptase-RNaseH (p66) essential for the conversion of viral RNA into DNA (Fig. 2), a viral protease (p12) for the processing of the polyproteins, a dUTPase (p15) essential for EIAV replication in non dividing monocyte-derived macrophages, the natural host cells for EIAV expression and replication $[89,162,174]$, and an integrase.

The general organization of the env gene is similar to that described for other retroviruses. It codes for the surface (gp90) and transmembrane (gp45) glycoproteins, incorporated into the virus envelope (Figs. 1A and 2). Gp90 may interact with the cellular receptor, still unknown for EIAV. EIAV gp90 is highly glycosylated; based on the deduced amino-acid consensus sequence of EIAV $_{\mathrm{PV}}, 17$ and 5 potential N-linked glycosylation sites (NX[S/T]) are present in gp90 and gp45 respectively [81]. During the course of disease, the gp90-surface glycoprotein is subjected to rapid evolution. We showed that the mutations are restricted to defined variable regions, $\mathrm{V} 1$ to V8, in gp90 [81] (Fig. 1C). We will discuss this point in detail later in this review.

\subsection{Function of the EIAV LTR (Long Terminal Repeat)}

Lentiviral Long Terminal Repeats (LTR) (Fig. 1A) serve as the site of transcriptional initiation; they contain three segments namely U3 (unique, 3' end), R (Repeated) and U5 (unique, 5' end). The U3 region contains several elements important for viral transcription. The lentivirus promoters are regulated by various cellular DNA-binding factors interacting with specific motifs on the LTR sequence. EIAV LTR contains cis-acting DNA elements corresponding to the methylated DNA-binding protein site MDBP, two PEA2 elements, a PEA3/ets motif and an AP-1 site [16]. The EIAV promoter is positively regulated by PU.1 (purine-rich element 1) recognizing the ets element [17]. PU.1 expression is normally restricted to the haematopoietic system and is absolutely required for the generation of B-lymphocytes and macrophages (reviewed in [93]), the natural target of EIAV infection. 


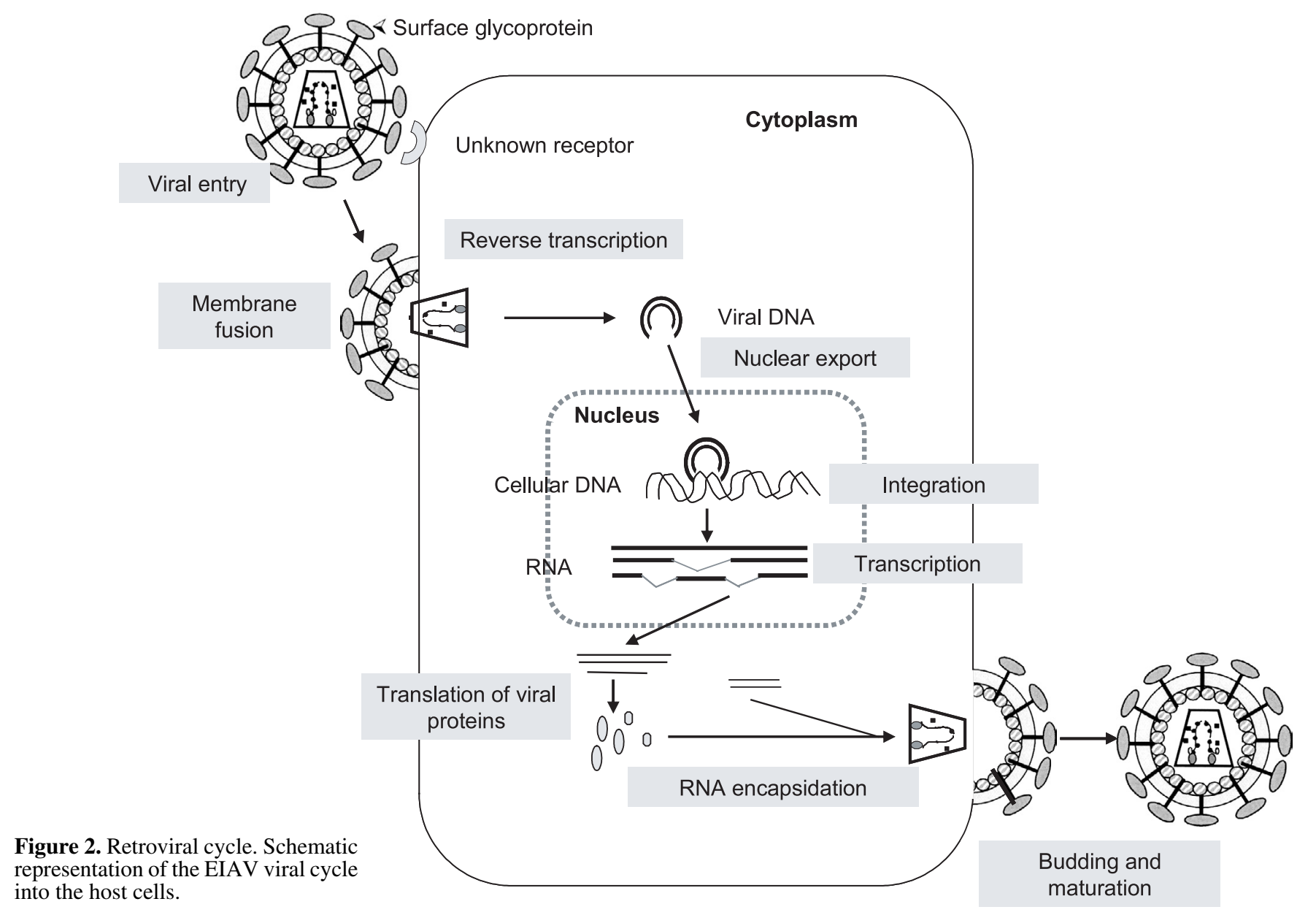




\subsection{Tat, Rev and S2: the accessory proteins of EIAV}

The EIAV genome contains only three additional open reading frames with the capacity to encode additional small accessory proteins (Fig. 1B). This is in contrast with the seven additional genes contained in the genome of the primate lentiviruses (reviewed in [173]). Functions have been assigned to the initially designated $\mathrm{S} 1, \mathrm{~S} 2$ and $\mathrm{S} 3$ proteins: $\mathrm{S} 1$ is a transactivator protein similar to HIV Tat, S2 is an accessory protein unrelated to other known lentiviral proteins and S3 corresponds to Rev. The basal transcriptional activity from the lentiviral LTR is usually low, with the activation being under the control of the Tat (Transactivator of Transcription) protein. A Tat function has been localized in a region between the pol and env genes of EIAV (Fig. 1B) [36, 158]. The structural analyses revealed a well defined hydrophobic core and two flexible $\mathrm{NH}_{2}$ and $\mathrm{COOH}$ terminal regions [165, 185]. EIAV Tat interacts with the viral LTR through the trans-activation responsive (TAR) element. The secondary structure of TAR is essential for Tat action; the TAR RNA-stem loop is closed by two $U^{*} G$ base pairs and the conservation of the nucleotide sequence of the loop is essential $[15,59,60]$. As for HIV, it is clear that the transcription of EIAV DNA in the cell is controlled by the interaction between the viral TAR sequence and the viral Tat protein. Through its interaction with TAR, HIV Tat recruits transcriptional complexes to the viral promoter, including enzymes with histone and acetyl transferase factor activity and the positive transcription elongation factor $b(\mathrm{P}-\mathrm{TEF})$ complex. The $\mathrm{P}-\mathrm{TEFb}$ complex enhances the elongation activity of the RNA polymerase II complex and is minimally composed of the CDK9 kinase and cyclin T1 (reviewed in [11,88]). A similar mechanism involving cyclin T1 has been described in the context of the EIAV Tat and TAR interaction suggesting that highly divergent Tat and TAR elements control viral gene expression by the same mechanism $[1,9,167]$. Interestingly, recent studies on the initially named Tat protein of Small Ruminant Lentiviruses (SRLV), infecting goats and sheep, showed that this protein has a minimal effect on the transcriptional level from the LTR [181]. In fact, the gene initially designed as the tat gene may encode a Vpr-like protein, suggesting that SRLV differ from the other lentiviruses in their control of expression from the viral LTR [180].

The S2 gene overlaps the N-terminus of the envelope coding region [153]. The small S2 protein (65 amino acids) contains 3 amino-acid motifs highly conserved during persistent infection: a putative nucleoporin motif (GLFG), a putative SH3 domain binding motif (PXXP) and a putative nuclear localization domain (RRKQETKK) [86]. S2 is expressed during EIAV infection in horses as shown by detection of antibodies directed against $\mathrm{S} 2$ in experimentally and naturally infected animals [153]. S2 is a cytoplasmic protein potentially interacting with Gag but not incorporated into the EIAV particles [186]. The role of $S 2$ remains unclear but mutational studies of this gene in the context of EIAV $V_{\mathrm{UK}}$, a pathogenic molecular clone [28], revealed that $\mathrm{S} 2$ is dispensable for viral replication in vitro in several equine cell lines and in monocytederived macrophages [85], but is an important determinant of viral replication and virulence during in vivo infection [86]. Interestingly, the $\mathrm{S} 2$ open reading frame is absent in V26, an attenuated EIAV, obtained by serial passage in primary horse macrophages [76, 191].

Complex molecular mechanisms allow differential expression of viral protein from the relatively small lentiviral genomes. One strategy used by lentiviruses is the alternative RNA splicing, leading to the production of various mRNA from a single RNA precursor. This strategy requires sub-optimal splice sites allowing the production of several mRNA from a single pre-RNA. Transcription from the EIAV LTR leads to the production of full-length genomic and 
singly spliced mRNA encoding the major Gag, Pol and Env proteins and of small multi-spliced transcripts encoding the Tat, S2 and Rev proteins [140, 164]. Most cellular mRNA are fully spliced before export into the cytoplasm, the need for unspliced or partially spliced RNA has to be satisfied in lentivirus-infected cells. Rev (regulator of expression of viral proteins) acts posttranscriptionally by allowing the essential translocation of unspliced and partially spliced RNA from the nucleus to the cytoplasm. In this context, functional Rev is absolutely required for expression of structural proteins [100] and virus production. EIAV Rev mediates mRNA transport from the nucleus to the cytoplasm through a Revresponsive element (RRE) located near the end of the env gene [6,100]. A recent study has precisely located the EIAV-RRE to a 55-nucleotide region proximal to the 5' splice site of exon 3 RNA [21]. Unlike the RRE structures from other retroviruses, EIAV cis-acting sequences do not form a clear secondary structure [100].

\section{CLINICAL FEATURES OF THE EIAV-INDUCED DISEASE}

\subsection{Control of EIAV infection}

EIA is considered a worldwide disease but is, due to its transmission by insect vectors, predominant in warm climates [64]. In 1970, a reliable serological test based on agar gel immunodiffusion (AGID) using p26 antigen was developed $[24,25]$. The "Coggins Test" rapidly gained recognition as an efficient way of detecting infected animals. It has been qualified as the standard diagnostic for EIAV infection by the United States Department of Agriculture (USDA) and AGID is the only test officially recognized by the Office International des Epizooties (OIE). To limit virus spread, horses are routinely tested before being allowed into shows or racetracks, used for breeding or crossing borders. EIAV-seropositive animals are either euthanized or kept in quarantine for the rest of their life, depending on local regulations. The use of this test allowed the efficient control of EIAV infection in the United States. Between 1972 and 1984, the number of AGID-positive animals decreased from $3.9 \%$ to $0.38 \%$ [130]. The major drawback of this test is that it is time consuming and sometimes difficult to interpret. Different tests based on a competitive or non-competitive enzyme-linked immunosorbent assay (ELISA) have been developed and compared to the "Coggins test" [12, 37, 84, 160]. Recently, an EIAV diagnostic assay based on fluorescence polarization (FP) using a peptide derived from the gp45 transmembrane glycoprotein has been developed [172]. This technology is based on a change in fluorescence emission distinguishing between a small molecule such as a fluorescently labeled peptide and a large complex such as the same peptide bound to an antibody.

In France, the incidence of EIAV infection is low, with only 11 cases being detected between 1988 and 1992 but several outbreaks have developed recently [193]. In 1993 and 1994, a total of 59 animals coming from 17 herds were tested seropositive for EIAV [193]; an outbreak in southern France revealed the presence of 23 seropositive animals among the 60 present in the herd [193]. The situation then stabilized until 2000, when a new outbreak was reported with 41 infected horses coming from four herds [192, 193] (http:// www.aht.org.uk/icc/linksicc.html). In most cases, the origin of the contamination remains uncertain but may be linked to the introduction of animals into the herd. EIAV-positive animals are either euthanized, kept on their farm in isolation or sent to a research facility. In France, as in other countries, most horses are never tested for EIAV antibodies. In fact, only 12000 horses are tested yearly from an estimated population of 350000 equids [192]. EIAV-infected asymptomatic carriers may be the source of new infections. 


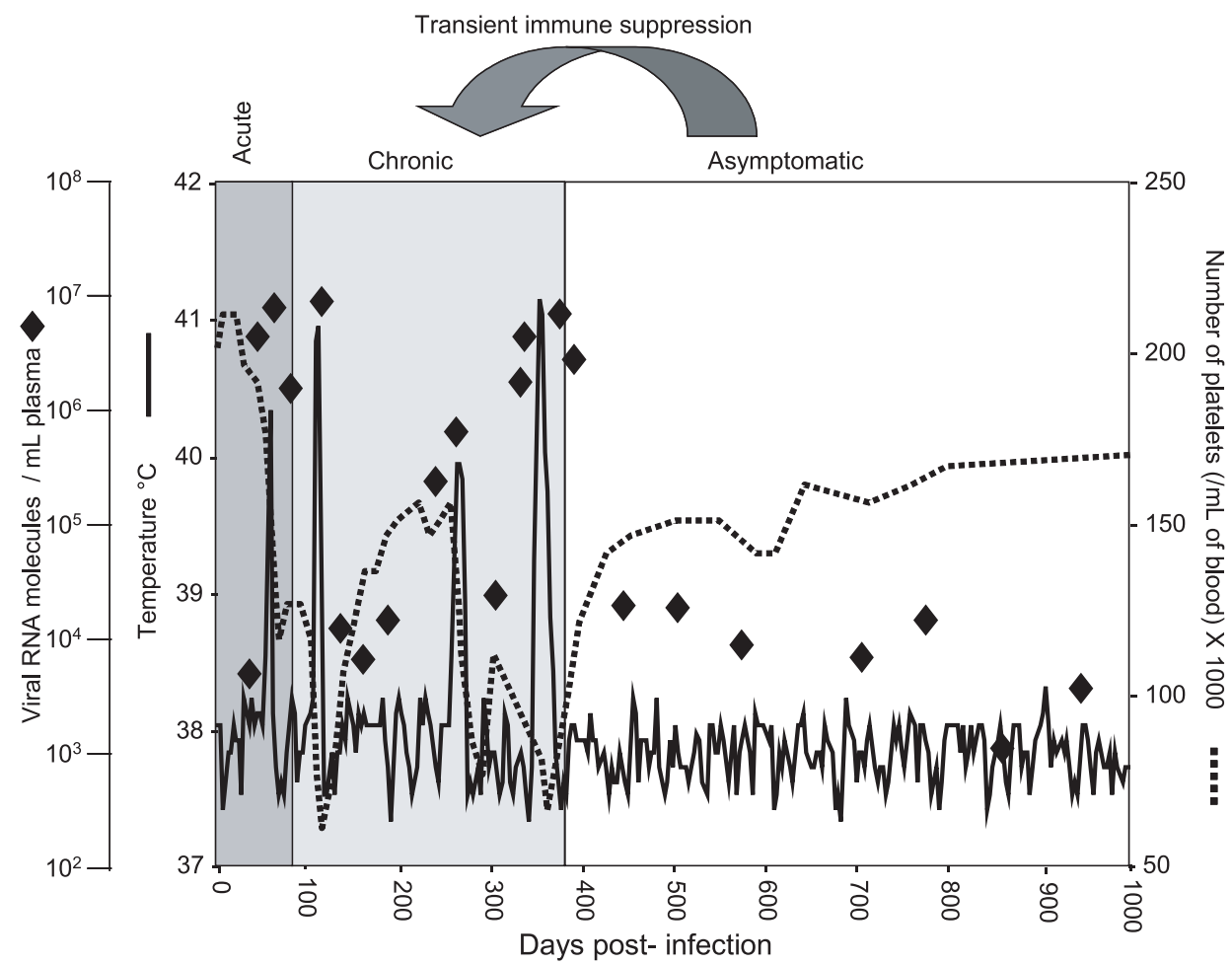

Figure 3. Clinical and virological profiles of ponies experimentally infected with EIAV. Febrile episodes are defined by a rectal temperature $(-)$ above $39^{\circ} \mathrm{C}$ in conjunction with a reduction of the platelets $(\bullet \bullet \bullet)$ below $100000 / \mu \mathrm{L}$ of whole blood. Viral RNA load in the plasma is indicated by $(\downarrow)$. EIA may be divided into three phases: acute, chronic and asymptomatic. As indicated by the gray arrow on top, asymptomatic animals may go back into chronic disease following naturally- or experimentally-induced immune suppression.

\subsection{EIA, a cyclic disease}

EIAV is unique among lentiviruses in that it causes a dynamic and defined course of infection and recurring disease in infected animals (Fig. 3). The sequences of clinical events, establishment of immune response and virus evolution have been well documented in horses and ponies (Equus caballus) [54, 55, 83, 124, 155]. Clinical, serological and virological responses after experimental infection of donkeys (Equus asinus) and detection of virus and description of the disease in mules (Equus caballus $\times$ Equus asinus) have been reported [30, 161]. While susceptible to infection, don- keys do not develop clinical EIA [30] and lower amounts of plasma associated virus and/or viral nucleic acids are observed in donkeys compared to ponies infected with the same strain of EIAV [30]. Viral RNA levels in ponies infected with the EIAV $V_{P V}$ virulent strain was 10000 fold higher than in the donkeys infected with the same strain during the first 20 days of infection [30]. However, in vitro infection of donkey or horse monocyte-derived macrophages yielded the same rate of EIAV production suggesting that factors other than cell permissiveness are involved in the differential clinical outcome [30]. This may be of interest, since several lines of evidence suggest 
a correlation between the level of virus replication and the severity of disease during lentivus infection in primates $[115,171]$. This concept of "pathogenic threshold" postulates that the level of viral replication must reach a critical level to induce disease.

EIAV is responsible for a persistent infection in horses that is characterized by recurring cycles of viremia and of clinical episodes associating fever, anemia, oedema, thrombocytopenia and various wasting symptoms. Based on experimental infection, we classically refer to acute, chronic and asymptomatic stages (Fig. 3). Initial exposure to a virulent strain usually results in an acute disease characterized by hyperthermia concomitant with a severe decrease of the platelet number. The animal may die from the acute or chronic disease, but in many cases these signs are relatively mild and may be overlooked. The acute episode usually subsides within a few days, then the animal enters the chronic stage of disease characterized by the recurrence of clinical cycles. If clinical episodes are frequent, the animal may develop classic clinical disease associating anemia, weight loss and oedema [63]. In practice, the course of disease may be clearly distinct in animals infected with the same strain of EIAV [29, 54, 83]. Experimental infection of ponies with EIAV $V_{P V}$ gives a different pattern of disease evolution with animals referred to as disease progressors, experiencing multiple disease cycles, or nonprogressors, free from clinical symptoms after the first acute viremia [54, 83]. Interestingly, the nonprogressor animals had an undetectable level of plasma virus RNA, as measured by sensitive quantitative RT-PCR while the progressor ponies consistently displayed $10^{4}$ to $10^{6}$ copies $/ \mathrm{mL}$ during the long-term asymptomatic infection [54, 83]. These observations suggest a fragile control of infection at subclinical levels. The basis for the difference in steadystate EIAV levels in inapparent EIAVinfected animals remains unclear. This may reflect differences in disease susceptibility.
In most but not all cases, lentiviral infections, including HIV-1 (Human Immunodeficiency Virus Type 1) in humans or SRLV (Small Ruminant LentiViruses) in goats and sheep, are responsible for slowly evolving progressive degenerative diseases leading to the death of the host after a few months or years. In contrast, in EIAVinfected equids, there is a transition from a chronic to an asymptomatic state, in which the animals remain free of clinical symptoms, but infected for the rest of their life. The animals are still infectious as demonstrated by whole-blood transfer from inapparent EIAV-infected to naive animals [65]. This inapparent or asymptomatic stage is reversible. Experimental administrations of immunosuppressive drugs such as dexamethasone in long-term EIAV-infected horses lead to overall immune suppression and the recrudescence of disease $[32,79,177]$. Many animals never show any recognizable signs of EIAV and continue to exist as asymptomatic carriers of the virus. They can be detected during routine serological tests in the context of herd evaluation [63].

\subsection{Physiopathology}

Thrombocytopenia is the earliest and most consistent abnormality observed in febrile animals. It is commonly used to monitor animals during experimental EIAV infections. Immune-mediated platelet destruction or direct infection of megakaryocytes have been described during thrombocytopenia associated with several infectious diseases [2, 96, 97, 195]. Thrombocytopenia is observed during HIV-1 infection. In contrast to other haematological disorders, a decrease in blood platelets is an early event, generally described within the first two years of HIV infection [48]. Thrombocytopenia may be due to either a decrease of proliferation of megakaryocyte progenitors or inhibition of megakaryocyte maturation. As shown by in situ hybridization, megakaryocytes present in the spleen do not support EIAV replication [22] despite a marked reduction in platelet number. In 
EIAV-infected horses, elevated levels of platelet-bound $\operatorname{IgG}$ and $\operatorname{IgM}$ on washed platelets [22] and splenomegaly and hepatomegaly at necropsy are consistent with immune mediated platelet destruction. Thrombocytopenia may be explained by immune-complex deposition and subsequent degradation by mononuclear phagocytes. But the observation of a severe platelet decrease in severe combined immunodeficient (SCID) horses, lacking functional $\mathrm{T}$ and $\mathrm{B}$ lymphocytes, suggests that nonimmune mediated mechanisms may be involved during EIAV-associated thrombocytopenia [33]. Impairment of platelet production may also be under control of circulating factors released by infected-macrophages. TNF $\alpha$ (Tumor Necrosis Factor alpha) and TGF $\beta$ (Transforming Growth Factor beta) are produced by macrophages and are known to have a suppressive effect on megakaryocyte genesis. Elevation of TNF $\alpha$ and TGF $\beta$ has been described in days preceding the onset of thrombocytopenia [175]; Costa et al. [31] described a strong correlation between TNF $\alpha$ production, virulence of the infecting agent and clinical outcome in vaccinated and infected animals. TNF $\alpha$ and TGF $\beta$ may be released by macrophages upon EIAV infection and an increase in TNF $\alpha$ production has been shown to coincide with the onset of fever in African Swine Fever for example [151]. TNF $\alpha$ has a direct effect on hyperthermia by directly stimulating hypothalamic prostaglandin biosynthesis [71]. TNF $\alpha$ suppresses erythropoiesis in vitro $[38,116]$ and may participate in the observed haemolytic anemia in EIAV-infected animals in addition to the described erythrophagocytosis associated with the $\mathrm{C} 3$ fraction of the complement [156]. Similar indirect mechanisms have been described during HIV-associated thrombocytopenia. Viral transcripts have been detected in vivo in megakaryocytes of HIV-1 infected patients [96, 194] but direct infection of haematopoietic cells does not seem to occur [97]. Bone marrow progenitors are not infected, but increased viral replication in the bone marrow microenviron- ment may participate in the impairment of CD34+ haematopoietic stem/progenitor cells [187]. Antibodies directed against platelets detected in the sera of HIV infected patients may also contribute to an immune-mediated destruction of circulating platelets [187].

\subsection{Cell tropism and strains of virus}

Experimental infections by EIAV have identified active replication in various tissues such as the spleen, liver, lung, lymph nodes or bone marrow [107, 143, 154], specifically in mononuclear phagocytes. As for other human and animal lentiviruses, the cells of the monocyte/macrophage lineage are the primary targets of EIAV in vivo. They support active viral replication during clinical and subclinical infection [124]. Viral RNA has also been detected in vascular endothelial cells in experimentally infected horses during the acute phase [125] but not during subclinical infection [124]. In vivo infections of endothelial cells may contribute to the observed thrombocytopenia in infected animals by subtle changes or activation of these cells resulting in the promotion of platelet adherence or aggregation, as proposed in HIV infected patients. Blood monocytes are permissive for EIAV infection [154], but monocyte differentiation to mature macrophages is an essential step for EIAV replication [102]. Whereas EIAV infects monocytes in vivo, viral expression occurs only upon macrophage differentiation within an organ. Peripheral blood monocytes allow virus entry and reverse transcription of the viral RNA but do not support active replication. Acute disease is associated with extensive viral replication in tissue macrophages [154]. Interestingly, the same type of restriction is observed with SRLV infection in goats and sheep, for which viral expression occurs only in macrophages [23, 46, 47, 120]. This mechanism has been referred to the "Trojan Horse", where the virus silently enters the organ via an infected monocyte [50, 132]. 
A number of primary cells or cell lines have been used to propagate EIAV in vitro. Infection can be performed in vitro in various equine cells such as monocyte-derived macrophages [74, 102, 137], tissue macrophages derived from the spleen [137] or bone marrow [89], endothelial cells [104] or fibroblasts $[72,77,99]$ and in canine and feline transformed cell lines [8, 10, 58, 72].

Several strains of EIAV have been studied; they greatly vary in terms of virulence and ability to grow in cell culture. Most EIAV strains studied in laboratories worldwide are derived from the highly virulent Wyoming strain [70] or from the V26 Japanese EIAV strain [76]. Most horse-virulent EIAV strains only replicate in primary horse macrophage cultures and cannot replicate in tissue-derived cell lines without extensive adaptation leading to a marked reduction of in vivo virulence $[13,76]$. In vitro macrophage tropism tends to correlate with higher in vivo virulence. The virulence of cell adapted EIAV may be restored by serial passage through Shetland ponies [49, 126]. Primary horse macrophage cultures are intrinsically difficult to obtain and to maintain in vitro for long periods of time. New tools are now available with a reliable method of isolation and maintenance of monocyte-derived macrophages [137] and there are recent reports of efficient replication of EIAV in DH82 cells, an adherent canine macrophage-like cell line [58]. Most interestingly, these cell systems support the replication of both macrophage tropic and fibroblast-adapted EIAV strains. The attenuation of EIAV virulence in cell culture suggests that virulence determinants may be lost or altered when viruses are propagated in cells other than their natural target. To better characterize the molecular determinants of pathogenicity and cell tropism, several laboratories have tried to develop full-length EIAV molecular clones. Obtaining infectious and pathogenic molecular clones turned out to be challenging. A full length clone CL22 [184] was obtained from canine foetal thymus cells (Cf2Th) infected with the Malmquist strain of EIAV, derived by adaptation of the Wyoming strain on equine dermal fibroblasts [99]. Viruses derived from the CL22 clone were able to establish a persistent infection in inoculated horses but did not cause clinical disease [184]. In a similar manner, viruses derived from the pSPEIAV19 and pSPEIAV44 clones recovered from foetal equine kidney (FEK) cells infected with the EIAV $V_{P V}$ (pony virulent) strain, an in vitro variant of the Wyoming strain, were infectious but non-pathogenic for experimentally infected ponies [128]. Recently, in two parallel studies, replacement of the 3' half (env and LTR) of the pSPEIAV19 with the corresponding regions obtained from the highly pathogenic EIAV ${ }_{\text {wyoming strain [129] or }}$ from the pathogenic EIAV $V_{P V}$ variant [28] restored the pathogenic properties of the viruses derived from the molecular clones. These results suggest that important determinants of pathogenicity are present in the 3' half of pathogenic EIAV. The origin of the 3' half region determined the level of pathogenicity. The inoculation of the ponies with p19/wenv17-derived viruses carrying the env and LTR regions of EIAV $_{\text {wyoming }}$ induced a disease so severe that the animals had to be euthanized [129]. This is very similar to what is observed during EIAV $\mathrm{wyoming}_{\text {infection. The incidence }}$ of disease induced in equids was found to be significantly lower with EIAV $_{\mathrm{UK}^{-}}$-derived viruses than with the parental EIAV $V_{\mathrm{PV}}$ infection, from which we generated the clone [28]. In several other studies, EIAV $\mathrm{UK}_{\mathrm{UK}}$ was shown to have a disease induction rate of $43 \%$ compared to $87 \%$ using the parental EIAV $_{\text {PV }}[28,86]$. Genetic divergence between EIAV $_{\mathrm{UK}}$ and $\mathrm{EIAV}_{\mathrm{PV}}$ is restricted to a replacement of arginine $\left(\mathrm{R}_{103}\right)$ by tryptophan $\left(\mathrm{W}_{103}\right)$ in the ORF S3 and to a $68 \mathrm{pb}$ duplication in the EIAV $V_{\mathrm{UK}}$ 3'LTR [28] probably originating from a minor genetic form in EIAV $V_{P V}$ stock. Soon after the inoc-

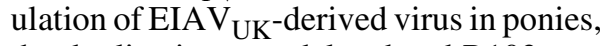
the duplication was deleted and R103 was replaced by W103 [28] suggesting that a strong in vivo selection generates virus populations resembling the optimal EIAV $V_{P V}$ 
sequence. Recently, variation in the 3' half has been associated with a novel cytolytic strain of EIAV, vMA-1c, that rapidly and specifically kills equine dermal (ED) cells [106]. Several studies described the importance of the enhancer region of the U3 region of the LTR in cell tropism $[14,98$, 102]. Three PU.1 binding motifs described in most strains of EIAV are required for LTR expression in primary macrophages [102]. Interestingly, the introduction of these PU.1 sites in the HIV-1 enhancer/promoter proximal region of the LTR resulted in macrophage-specific expression [141]. Other enhancer motifs such as PEA-2, Oct, and CRE sites are important for expression in fibroblasts [105]. The repertoire of transcription-factor binding motifs appears to be different in the natural target of EIAV infection and in the cells used in vitro to propagate the virus.

\section{IMMUNE CONTROL OF EIAV INFECTION AND REPLICATION}

EIAV infection results in a high-titer, infectious plasma viremia within three weeks post infection. Several lines of evidence suggest that both humoral and cellular EIAV-specific responses are needed to terminate the initial viremia. As we mentioned previously, viral replication is efficiently reduced to a subclinical level in animals evolving from the chronic stage to the asymptomatic stage of EIAV infection. In long-term inapparent EIAV-carriers, a low level of virus infection and replication can be detected in tissue macrophages [55, 124] and associated with plasma viremia [54, 83]. The importance of the immune response in this control was rapidly indicated by experimental immune suppression in asymptomatic animals leading to the recrudescence of disease symptoms, even after several decades of infection [79, 177]. Arabian foals with severe combined immunodeficiency (SCID), lacking both B and T lymphocytes, fail to control the initial viremic episode [33, 108, 133]. Adoptive transfer by intravenous infusion of EIAV-stimulated donor lymphocytes in SCID foal restores the control of viral replication in the reconstituted animal $[112,113]$. Studies examining the evolution of plasma-associated viral RNA load together with the development of clinical symptoms suggest that the threshold level for disease induction correlates with an RNA level in plasma of $10^{7}$ to $10^{8}$ copies/mL $[29,32,54,83]$. All these studies suggest that during the course of EIAV infection, the host develops a highly effective and enduring immune response able to maintain viral replication below the threshold level for disease induction. The clearance of the primary infectious plasma viremia correlates with the emergence of EIAV-specific $\mathrm{CD}^{+}$cytotoxic T lymphocytes (CTL) and non-neutralizing EIAV-specific antibodies [110, 133, 150]. EIAV infected animals develop a strong immune response against the surface (gp90) and transmembrane (gp45) glycoproteins and the major core protein p26. Although p26 is the most abundant protein in the virion, the humoral response against p26 is 10 to 100 -fold lower than the reactivity against gp90 and gp45 [51, 123]. Antibodies that recognize EIAV reverse transcriptase have also been described in experimentally and naturally EIAV infected animals [35].

As described in HIV-1 infected patients [80], the appearance of CD8 ${ }^{+}$CTL correlates with the clearance of the initial viremia [110]. Later in the infection, many animals develop abundant $\mathrm{CD} 4^{+}$and $\mathrm{CD} 8^{+}$memory CTL (CTLm) recognizing EIAV antigens $[51,54,111,189] . \mathrm{CD}^{+}$CTL recognize and lyse both Gag- and Env-expressing targets, whereas $\mathrm{CD} 4^{+}$CTL lyse only Envspecific target cells [51]. CTL epitopes have been mapped within Gag matrix (p15) and capsid (p26) [95, 188], surface glycoprotein (gp90) [94] and Rev, including the nuclear export and the nuclear localization domains [114]. In a recent study, high- or moderate-avidity CTLm targeting Revepitopes have been found in nonprogressor EIAV-infected animals, suggesting that CTL 
response against a non-variable viral peptide may be a critical element for virus control [114]. Interestingly, as previously described during HIV and SIV infections in primates [39, 45, 69, 119], viral evolution in EIAV-gag and env genes led to CTL escape [114]. EIAV-neutralizing antibodies that are able to block the infecting strain usually emerge only after two or three months post infection [5, 51, 61, 75, 123] suggesting that they are not responsible for the termination of the acute episode. In a longitudinal study, no correlation was observed between the level of neutralizing antibodies and the course of the infection [51]. Neutralizing antibodies do not reach a steadystate level but tend to fluctuate markedly during the course of infection [51]. The role of neutralizing antibodies in controlling EIAV replication is still unclear and complex. A lack of correlation between neutralizing antibody levels and protection has been reported in several studies in infected $[51,117,150]$ or vaccinated [66] animals. This is in contrast with the reported efficiency of high-titer neutralizing antibodies directed against the HIV-1 envelope to completely block HIV/SIV chimeric virus infection in macaque monkeys [121, 159]. Recrudescence of disease is, however, associated with the emergence of neutralization-escape variants [75, 82, 83, 117], suggesting that the neutralizing response is in fact efficient in controlling virus replication. Three neutralization epitopes, $\mathrm{C}_{\mathrm{NT}}$, $\mathrm{D}_{\mathrm{NT}}$ and $\mathrm{E}_{\mathrm{NT}}$, have been mapped on the surface glycoprotein gp90; $\mathrm{D}_{\mathrm{NT}}$ and $\mathrm{E}_{\mathrm{NT}}$ constitute the principal neutralizing domain (PND) [5]. Inoculation of ponies with virus particles derived from an EIAV molecular clone lacking the PND region showed that the animals were able to control disease in the absence of a detectable neutralizing response [32]. Following dexamethasone treatment, the transiently immune-suppressed ponies developed characteristic EIA, that became controlled concomitantly with the development of a neutralizing response, suggesting that a region other than the PND may be involved in the neutralizing response
[32]. In a recent study, we determined the sensitivity of five sequential variant envelope glycoproteins [81] to neutralization by a longitudinal panel of immune sera from the source infected pony by exchanging regions of neutralization-sensitive and neutralization-resistant envelopes [61]. We demonstrated the influence of sequential gp90 variation in increasing envelope neutralization resistance, identified the V3 and V4 variable regions of gp90 as the principal determinants of neutralization resistance and suggested the importance of complex cooperative envelope domain interaction in defining this resistance [61].

Looking in detail at the humoral response during the progression from chronic disease to inapparent stages, Hammond et al., $[51,54]$ described a gradual evolution of the humoral response over the first 10-months post infection. During this time period, EIAV-specific antibodies matured from low avidity, measured by the stability of the antibody-antigen complexes, to reach a steady-state level of moderate to high avidity [51, 54]. A change in conformationdependence has been reported with the initial envelope-specific antibodies mainly recognizing linear epitopes, evolving toward a conformation-dependent response [51]. A similar evolution of these immune parameters has been shown in experimentally infected animals, regardless of their profiles of disease evolution after the first acute viremia [54].

Interestingly, studies in SIV or SIV/ HIV-1 infected monkeys [26, 27, 118] and HIV-1 infected patients [27] revealed a common theme of antibody maturation during the first 6 to 10 months post-infection, that is characterized by ongoing changes in antibody titers, conformational dependence and antibody avidity. Antibody-dependent cellular cytotoxicity (ADCC) is lacking during all stages of EIAV infection [44, 176]. These different studies certainly indicate the role of an efficient and mature immune response (Fig. 4) in controlling 

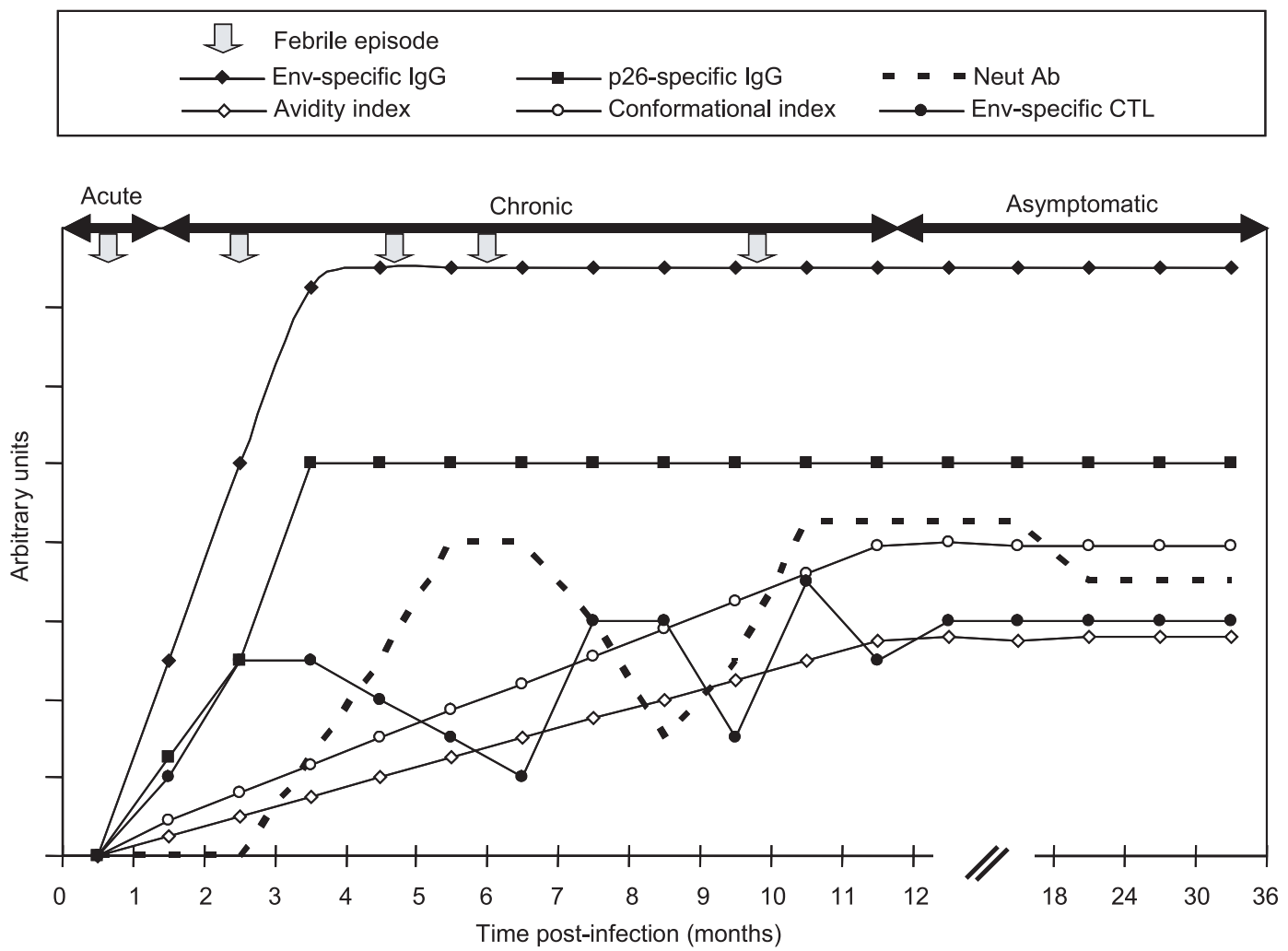

Figure 4. Maturation of the immune response in EIAV-infected animals (from [51,54]). The figure represents the evolution of the EIAV-specific antibody response (Env-specific IgG and p26-specific IgG) and of the EIAV-specific cellular response (Env-specific CTL). During the first 10-months of infection, the antibody population evolves gradually from a population characterized by low-avidity, non neutralizing and predominantly linear epitope specificity to an antibody population characterized by moderate to high-avidity, neutralizing and predominantly conformational epitope specificity. Neutralizing antibodies appear only after 2 to 3 months of infection. Immune parameters are expressed in arbitrary units according to the time post infection. 
EIAV replication. But, correlates of immune protection remain to be clearly defined.

\section{VIRAL EVOLUTION IN INFECTED ANIMALS}

Lentiviruses are among the most rapidly evolving genomes. Three polymerization events occur during the retroviral cycle: the generation of a double-stranded DNA from the viral RNA by the reverse transcriptase, the replication of the integrated viral DNA by cellular DNA polymerase and the RNA synthesis by cellular RNA polymerase II. Low fidelity of the lentiviral reverse transcriptase, which lacks proofreading activity $[134,147]$ and recombination of genomes within coinfected cells [148] contribute to an elevated mutation rate. EIAV RT is as error prone as HIV-1 RT and shows efficient mismatch extension during the copying of both RNA and DNA templates [4]. The fidelity of EIAV RT, as with other RT enzymes, is sequence related; purine-pyrimidine mispairs are more efficiently extended than the purine-purine mispairs [4]. A high level of variations can be observed between and within the lentivirus-infected host. Lentiviruses exist in vivo as complex populations of related, but not identical, viral genotypes or quasispecies. LTR regions, rev and env have been shown to accumulate nucleotide mutations. Studies on the evolution of the LTR during EIAV infections yield some controversial results. A hypervariable region has been described in the $\mathrm{U} 3$ region of the LTR, by comparing the highly pathogenic EIAV $V_{\text {wyoming }}$ strain and the biological MA-1 variant selected by in vitro replication on equine dermal (ED) cells [14]. The same region has been defined as a hot spot of mutation by comparing U3 LTR of isolates obtained from naturally infected animals [103]. This interesting study highlighted the natural variation of field isolates of EIAV. In contrast, we described a very low rate of mutation of the LTR during experimental infection of ponies with the EIAV $V_{P V}$ strain either in the virus present in the plasma $[81,90]$ or that in various reservoir tissues [142]. These apparently contradictory reported results may be due to the origin of the viruses studied and the duration of infection. A hypervariable region of the U3 LTR has been described in the context of cell-adapted EIAV. For example, the MA-1 variant of EIAV $_{\text {wyoming }}$ was selected by in vitro adaptation in equine dermal cells [14]. LTR variants have been shown to be rapidly eliminated in vivo [29, 91]. LTR variations are associated with in vitro adaptation to nonnatural target cells such as non-equine cells or fibroblasts; in vivo replication probably requires a rapid adaptation of the LTR. Mutations in rev have been reported in several studies $[3,7,81]$. Interestingly, a rev variant present during chronic EIA had significantly higher Rev-mediated nuclear export activity than the variant sequenced during afebrile periods, suggesting that the genetic variation of rev may contribute to EIAV disease progression [3, 7].

It is well established that cycles of disease correlate with the emergence of antigenic variants of the surface glycoprotein $[78,117]$. Virus neutralization assays established that plasma neutralizes virus isolates recovered during earlier febrile episodes, but fails to neutralize virus isolates recovered from subsequent febrile episodes [117, 152]. Comprehensive studies on the evolution of the surface gp90 glycoprotein revealed that mutations occur rapidly after experimental infection of ponies with the American EIAV $V_{P V}$ [81] or horses with the Japanese virulent EIAV strain V70 [190] These two parallel studies with viruses from different geographical origins showed that these mutations are not randomly distributed along gp90 but delineate variable regions $[81,190]$. We defined eight variable regions, rapidly evolving after EIAV inoculation (Fig. 1C).

New predominant quasispecies are associated with each clinical episode and the circulating viral populations are completely replaced between febrile episodes (Fig. 5) 


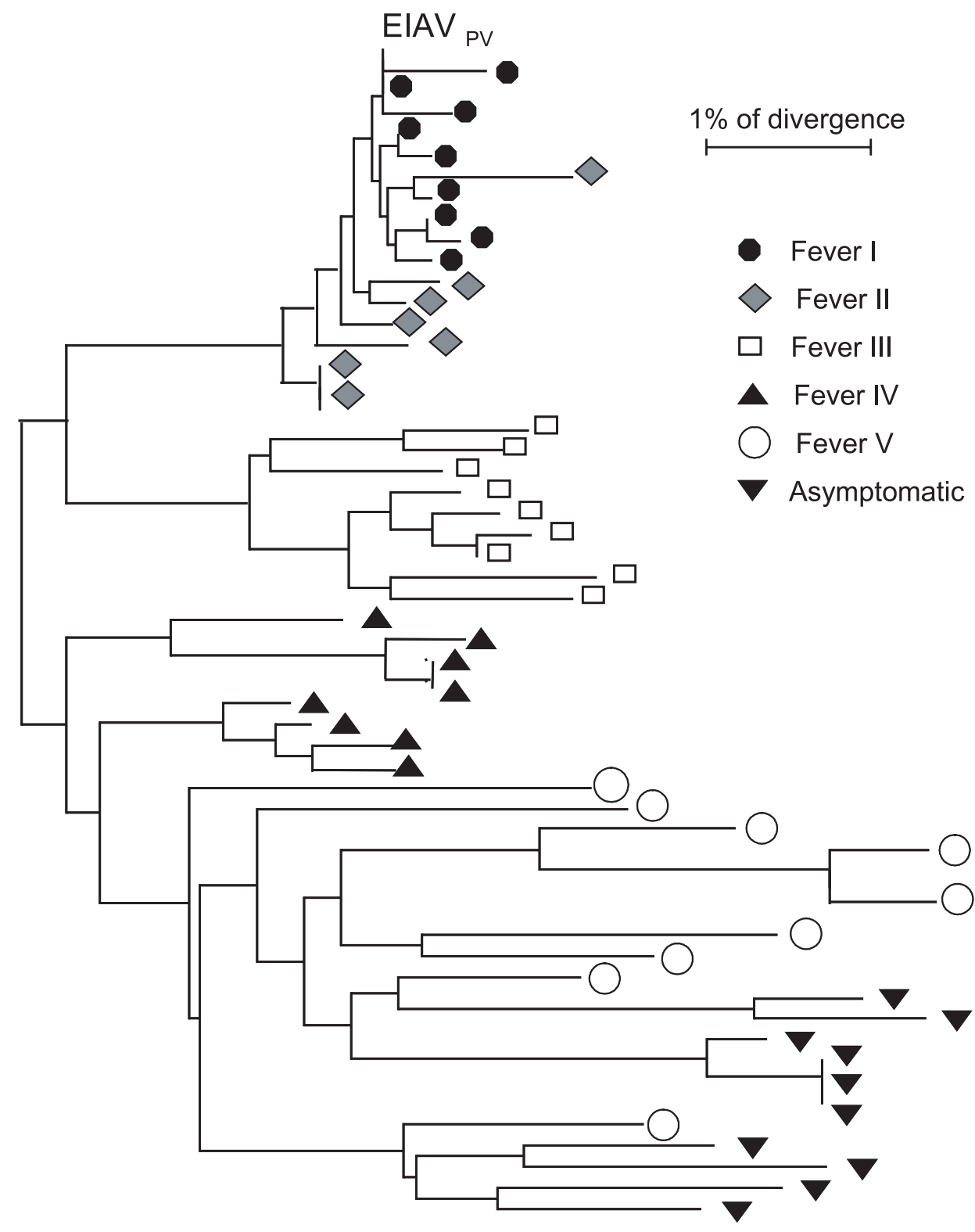

Figure 5. Evolution of the surface glycoprotein gp 90 in an experimentally infected pony (from [81, 83]). Phylogenetic study of gp90 deduced amino-acid sequences of longitudinal viral isolates obtained from plasma during EIAV-induced fevers I $(\mathbf{O})$, II $(\diamond)$, III $(\square)$, IV $(\boldsymbol{\Delta})$, V $(\bigcirc)$ shows that recrudescence of fever is associated with the emergence of new viral populations during the chronic phase of EIA. Evolution of gp90 continues during the asymptomatic stage of infection as shown by viral populations recovered from monocyte-derived macrophages during the asymptomatic stage $(\boldsymbol{\nabla})$, suggesting a continuous viral replication. Branch lengths are proportional to the distance between the sequences. 


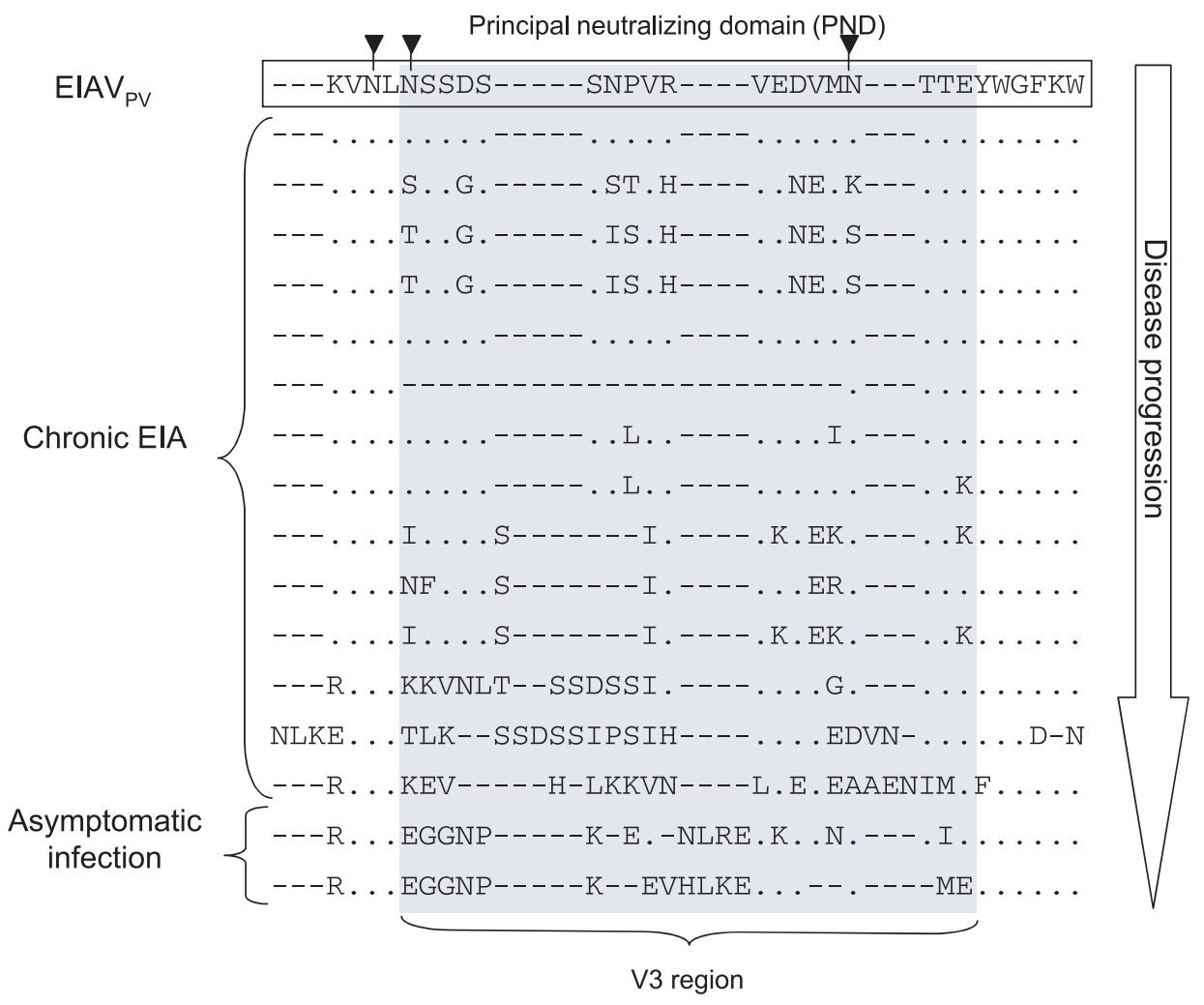

Figure 6. Evolution of the third variable region (V3) of gp90 during the course of infection in a

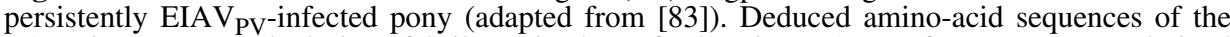
V3 region recovered during febrile episodes of chronic EIA or from monocyte-derived macrophages obtained during the asymptomatic stage are compared to the inoculated strain EIAV $_{\mathrm{PV}}$. Only amino-acid residues different from the EIAV $\mathrm{PV}_{\mathrm{P}}$ sequence are indicated. Dots indicate residues identical to the $\mathrm{EIAV}_{\mathrm{PV}}$ sequence; dashes indicate amino-acid deletions; triangles ( $)$ indicate potential N-glycosylation sites (NX[S/T]). The gray box indicates the Principal Neutralizing Domain (PND).

[81, 190]. Point mutations, insertions and deletions are observed during the dynamic evolution of the gp90 quasispecies, mainly in the $\mathrm{V} 3$ region corresponding to the PND (Fig. 6). Up to $80 \%$ of the amino acids of $\mathrm{V} 3$ have been replaced in vivo in EIAV $\mathrm{V}_{\mathrm{PV}}$ infected ponies [83]. Interestingly, we showed that a large deletion of up to 15 amino-acids, removing virtually all the PND region, did not alter the competence for in vitro [81] or in vivo replication [32]. Multiple mutation, repositioning or creation of potential $\mathrm{N}$ linked glycosylation sites (NX[S:T]) are observed during long term infection (Fig. 6)
$[81,83]$. The propensity for variations in gp90 glycosylation sites suggests that this post-translational modification is an important determinant of gp90 immunogenicity.

A widely accepted paradigm in lentivirus evolution is that the rate of variation is directly correlated to the level of virus replication. To test this hypothesis, we followed the EIAV gp90 evolution over a 2.5 year period in ponies that differed markedly in clinical progression. Surprisingly, the level of gp90 variation was independent of the number of disease cycles (only one in the nonprogressor ponies and 
Table I. Accumulation of mutation over a 2.5 year period in EIAV gp90 during the course of infection in disease progressor or nonprogressor EIAV ${ }_{\mathrm{PV}}$ infected ponies (adapted from [83]).

$\%$ of envelope divergence from the inoculated EIAV $_{\mathrm{PV}}$ measured at the deduced amino-acid level ( \pm mean standard deviation) during the different stages of the disease

\begin{tabular}{|c|c|c|c|c|c|c|c|}
\hline \multicolumn{8}{|c|}{ Non progressor ponies: } \\
\hline \multicolumn{7}{|c|}{ Fever \# 1} & Asymptomatic stage \\
\hline \multirow[t]{2}{*}{561} & 0.11 & \multicolumn{5}{|c|}{ No chronic disease } & NA \\
\hline & \pm 0.14 & & & & & & \\
\hline \multirow[t]{2}{*}{562} & 0.28 & \multirow{2}{*}{\multicolumn{5}{|c|}{ No chronic disease }} & 8.14 \\
\hline & \pm 0.21 & & & & & & \pm 0.37 \\
\hline \multicolumn{8}{|c|}{ Progressor ponies: } \\
\hline & Fever \# 1 & Fever \# 2 & Fever \# 3 & Fever \# 4 & Fever \# 5 & Fever \# 6 & Asymptomatic stage \\
\hline \multirow[t]{2}{*}{564} & 0.41 & 1.53 & 1.54 & 2.24 & 7.86 & 5.24 & 5.08 \\
\hline & \pm 0.34 & \pm 0.61 & \pm 0.55 & \pm 0.34 & \pm 0.96 & \pm 0.15 & \pm 0.17 \\
\hline \multirow[t]{2}{*}{567} & 0.41 & 1.01 & 5.12 & 3.22 & 7.46 & 7.67 & 7.44 \\
\hline & \pm 0.13 & \pm 0.38 & \pm 0.42 & \pm 0.35 & \pm 0.69 & \pm 2.29 & \pm 0.48 \\
\hline
\end{tabular}

Asympt: asymptomatic stage of infection, 2.5 years post infection.

NA: not applicable.

up to six in the progressor ponies) and of the apparent steady-state level of virus replication during long-term infection [83]. Regardless of the low levels of plasma viremia in long term infected ponies, the virus quasispecies evolve constantly [83], suggesting an active replication in reservoir tissues such as the liver, bone marrow or spleen [55] (Tab. I). Altogether, these studies show that mutations are clearly associated with the recurrence of EIA but, alone, are not sufficient to trigger viremia and disease. Disease progression does not correlate with the amount of accumulated mutations, as shown by the extent of mutation observed in nonprogressor animals (Tab. I) [83]. As we mentioned before, cellular and humoral responses are not clearly different in progressor and nonprogressor ponies, suggesting that other parameters control virus replication [54] and that emergence of a new viral population is not itself sufficient to induce clinical symptoms of EIA.

\section{EIAV VACCINE DEVELOPMENT}

The development of an efficacious vaccine against lentiviral infections remains a high priority in human and veterinary medicine. Despite international efforts and interesting results, no vaccine is actually available against HIV infection. Most naturally or experimentally EIAV-infected animals successfully control viral replication and disease within a few months. This innate ability to control lentivirus replication suggests that a vaccine against EIAV may be effective in controlling disease development. This made EIAV a unique model to test various vaccine strategies. Unfortunately, EIAV-vaccine development has only been moderately successful and classical vaccines based on inactivated or attenuated whole virus and on viral recombinant protein failed to elicit a broadly protective immune response. Twenty years ago, Chinese scientists reported a successful vaccine trial using a live attenuated EIAV strain produced by serial passages on donkey leukocyte cells [157]. But no independent investigations have been possible on this very promising vaccine trial and the results are not easily accessible to the international scientific community. Inactivated vaccine using the prototype cell-adapted Wyoming strain [99] efficiently protected 
ponies against a challenge with the homologous EIAV strain, but failed to prevent infection with an heterologous strain [66]. However, the level of replication of the challenge strain was significantly reduced. A subunit vaccine enriched in EIAV envelope glycoproteins not only failed to protect the vaccinated ponies against homologous or heterologous strains but had a high potential to enhance viral replication and to exacerbate clinical disease in challenged animals [66]. Disease enhancement has been described in FIV [67, 131, 144] or CAEV [73, 109] vaccine trials. In a similar manner, a recombinant subunit vaccine, containing a baculovirus-expressed EIAVenvelope surface glycoprotein, enhanced the disease in challenged ponies $[138,183]$. The severity of the disease after challenge ranges from a lack of clinical signs to severe exacerbation, with a correlation between the level of virus replication and the severity of the disease [138]. Antibody-dependent enhancement (ADE) and complementmediated antibody-dependent enhancement (C'-ADE) have been proposed as mechanisms of disease enhancement. ADE is a phenomenon in which virus-specific antibodies enhance the entry of virus into monocytes/macrophages and granulocytic cells through the interaction with $\mathrm{Fc}$ and/or complement receptors (reviewed in [169]). But in vitro ADE assays failed to correlate with the severity of the clinical symptoms observed in immunized ponies [139].

In a study comparing the humoral responses at the day of challenge elicited by attenuated, inactivated whole virus or envelope subunit vaccines, Hammond et al. [53] tried to determine the immune correlates of protection. No single parameter of the humoral response (titer, avidity index and conformational ratio) provided a statistically reliable correlate of protection. But interestingly, the level of protection after challenge does correlate with the development of a mature antibody response [53] as described during EIAV infection [51]. Encouraging results have been described with a live attenuated EIAV vaccine based on $\mathrm{EIAV}_{\mathrm{UK}} \Delta \mathrm{S} 2$, the molecular clone EIAV $_{\text {UK }}$ carrying two inactivating stop codons in the S2 open reading frame [87]. Immunization with EIAV $V_{\mathrm{UK}} \Delta \mathrm{S} 2$ provided protection from disease and detectable infection after challenge with a homologous EIAV strain, using low- or high-dose exposure [87]. The ability to confer sterile protection remains to be demonstrated with a heterologous strain. A vigorous CTL response is supposed to be a key parameter in the host immune response for the control of lentiviral infection. Targeting antigens into the phagocytic pathway is a strategy to induce a cellular response. In this context, a particulate vaccine, using gradient-purified EIAV complexed to iron oxide beads, was evaluated. Ponies vaccinated and challenged with an infectious EIAV strain have a delayed progression to disease and a lower virus load, but in most cases an absence of a CTL activity [52]. The protection after virus challenge has been correlated with a strong anamnestic response associating an increase in antibody titer, a conformationdependent envelope-specific response and emergence of a strong neutralizing activity [52]. Recently, lipopeptide immunization with MHC class I-restricted CTL epitopes from the surface glycoprotein proved to have a protective effect against EIAVinduced disease after challenge with a pathogenic strain [145, 146]. Taken together, these EIAV vaccines trials are encouraging but correlates of protection remain to be clearly defined. Protection against disease seems to be a reachable goal. Are the vaccinated ponies, like those in the asymptomatic phase, capable of carrying infectious EIAV or can vaccine immunity prevent virus transmission?

\section{CONCLUSION}

In conclusion, the rapid progression and the clear demarcation of the disease in EIAV-infection in equids offers a unique model with which to characterize natural immunologic control of lentivirus replication and disease and to elucidate the nature 
and role of viral variation in persistence and pathogenesis. One EIAV-intriguing feature is the ability of most animals to eventually control viral replication. Long-term infection is characterized by a fragile control of infection to subclinical levels. This control may be reversed by transient immunosuppression, suggesting a tight control of virus replication by the immune system.

Recurring episodes of EIA are associated with the dynamic evolution and replication of distinct EIAV quasispecies, that temporarily escape the established immune response. The evolution of the disease can be viewed as a fragile balance between the rapid viral evolution and an efficient immune response.

Clearance of the primary infectious plasma viremia correlates with the emergence of EIAV-specific CD8 ${ }^{+}$cytotoxic T lymphocytes and non-neutralizing antibodies. Then, a gradual evolution of the humoral response clearly develops over the first 10months post infection. Interestingly, studies in EIAV-infected equids, and SIV or SIV/HIV-1 infected monkeys and HIV-1 infected patients revealed a common theme of antibody maturation, that is characterized by ongoing changes in antibody titers, conformational dependence and antibody avidity.

Development of an efficacious vaccine against lentiviruses, such as HIV-1 and HIV-2, is a major challenge of this century. The innate ability of EIAV-infected equids to efficiently control viral replication within a few months could help us reach this goal.

\section{REFERENCES}

[1] Albrecht T.R., Lund L.H., Garcia-Blanco M.A., Canine cyclin T1 rescues equine infectious anemia virus tat trans-activation in human cells, Virology 268 (2000) 7-11.

[2] Axthelm M.K., Krakowka S., Canine distemper virus-induced thrombocytopenia, Am. J. Vet. Res. 48 (1987) 1269-1275.

[3] Baccam P., Thompson R.J., Li Y., Sparks W.O., Belshan M., Dorman K.S., Wannemuehler Y., Oaks J.L., Cornette J.L., Carpenter S., Subpopulations of equine infectious anemia virus
Rev coexist in vivo and differ in phenotype, J. Virol. 77 (2003) 12122-12131.

[4] Bakhanashvili M., Hizi A., Fidelity of DNA synthesis exhibited in vitro by the reverse transcriptase of the lentivirus equine infectious anemia virus, Biochemistry 32 (1993) 7559-7567.

[5] Ball J.M., Rushlow K.E., Issel C.J., Montelaro R.C., Detailed mapping of the antigenicity of the surface unit glycoprotein of equine infectious anemia virus by using synthetic peptide strategies, J. Virol. 66 (1992) 732-742.

[6] Belshan M., Harris M.E., Shoemaker A.E., Hope T.J., Carpenter S., Biological characterization of Rev variation in equine infectious anemia virus, J. Virol. 72 (1998) 4421-4426.

[7] Belshan M., Baccam P., Oaks J.L., Sponseller B.A., Murphy S.C., Cornette J., Carpenter S., Genetic and biological variation in equine infectious anemia virus Rev correlates with variable stages of clinical disease in an experimentally infected pony, Virology 279 (2001) 185-200.

[8] Benton C.V., Brown B.L., Harshman J.S., Gilden R.V., In vitro host range of equine infectious anemia virus, Intervirology 16 (1981) 225-232.

[9] Bieniasz P.D., Grdina T.A., Bogerd H.P., Cullen B.R., Highly divergent lentiviral Tat proteins activate viral gene expression by a common mechanism, Mol. Cell. Biol. 19 (1999) 4592-4599.

[10] Bouillant A.M., Nielsen K., Ruckerbauer G.M., Samagh B.S., Hare W.C., The persistent infection of a canine thymus cell line by equine infectious anaemia virus and preliminary data on the production of viral antigens, J. Virol. Methods 13 (1986) 309-321.

[11] Brigati C., Giacca M., Noonan D.M., Albini A., HIV Tat, its targets and the control of viral gene expression, FEMS Microbiol. Lett. 220 (2003) 57-65.

[12] Burki F., Rossmanith W., Rossmanith E., Equine lentivirus, comparative studies on four serological tests for the diagnosis of equine infectious anaemia, Vet. Microbiol. 33 (1992) 353-360.

[13] Carpenter S., Chesebro B., Change in host cell tropism associated with in vitro replication of equine infectious anemia virus, J. Virol. 63 (1989) 2492-2496.

[14] Carpenter S., Alexandersen S., Long M.J., Perryman S., Chesebro B., Identification of a hypervariable region in the long terminal repeat of equine infectious anemia virus, $\mathrm{J}$. Virol. 65 (1991) 1605-1610.

[15] Carvalho M., Derse D., Mutational analysis of the equine infectious anemia virus Tat- responsive element, J. Virol. 65 (1991) 3468-3474. 
[16] Carvalho M., Derse D., Physical and functional characterization of transcriptional control elements in the equine infectious anemia virus promoter, J. Virol. 67 (1993) 2064 2074.

[17] Carvalho M., Derse D., The PU.1/Spi-1 protooncogene is a transcriptional regulator of a lentivirus promoter, J. Virol. 67 (1993) 38853890 .

[18] Charman H.P., Bladen S., Gilden R.V., Coggins L., Equine infectious anemia virus: evidence favoring classification as a retrovirus, J. Virol. 19 (1976) 1073-1079.

[19] Chen C., Montelaro R.C., Characterization of RNA elements that regulate gag-pol ribosomal frameshifting in equine infectious anemia virus, J. Virol. 77 (2003) 10280-10287.

[20] Chen C., Li F., Montelaro R.C., Functional roles of equine infectious anemia virus Gag $\mathrm{p} 9$ in viral budding and infection, J. Virol. 75 (2001) 9762-9770.

[21] Chung H., Derse D., Binding sites for Rev and ASF/SF2 map to a 55-nucleotide purine-rich exonic element in equine infectious anemia virus RNA, J. Biol. Chem. 276 (2001) 1896018967.

[22] Clabough D.L., Gebhard D., Flaherty M.T., Whetter L.E., Perry S.T., Coggins L., Fuller F.J., Immune-mediated thrombocytopenia in horses infected with equine infectious anemia virus, J. Virol. 65 (1991) 6242-6251.

[23] Clements J.E., Gabuzda D.H., Gdovin S.L., Cell type specific and viral regulation of visna virus gene expression, Virus Res. 16 (1990) $175-183$.

[24] Coggins L., Norcross N.L., Immunodiffusion reaction in equine infectious anemia, Cornell Vet. 60 (1970) 330.

[25] Coggins L., Norcross N.L., Nusbaum S.R., Diagnosis of equine infectious anemia by immunodiffusion test, Am. J. Vet. Res. 33 (1972) 11-18

[26] Cole K.S., Rowles J.L., Jagerski B.A., Murphey-Corb M., Unangst T., Clements J.E., Robinson J., Wyand M.S., Desrosiers R.C., Montelaro R.C., Evolution of envelopespecific antibody responses in monkeys experimentally infected or immunized with simian immunodeficiency virus and its association with the development of protective immunity, J. Virol. 71 (1997) 5069-5079.

[27] Cole K.S., Murphey-Corb M., Narayan O., Joag S.V., Shaw G.M., Montelaro R.C., Common themes of antibody maturation to simian immunodeficiency virus, simian-human immunodeficiency virus, and human immunodeficiency virus type 1 infections, J. Virol. 72 (1998) 7852-7859.
[28] Cook R.F., Leroux C., Cook S.J., Berger S.L., Lichtenstein D.L., Ghabrial N.N., Montelaro R.C., Issel C.J., Development and characterization of an in vivo pathogenic molecular clone of equine infectious anemia virus, J. Virol. 72 (1998) 1383-1393.

[29] Cook R.F., Cook S.J., Berger S.L., Leroux C. Ghabrial N.N., Gantz M., Bolin P.S., Mousel M.R., Montelaro R.C., Issel C.J., Enhancement of equine infectious anemia virus virulence by identification and removal of suboptimal nucleotides, Virology 313 (2003) 588603.

[30] Cook S.J., Cook R.F., Montelaro R.C., Isse C.J., Differential responses of Equus caballus and Equus asinus to infection with two pathogenic strains of equine infectious anemia virus, Vet. Microbiol. 79 (2001) 93-109.

[31] Costa L.R., Santos I.K., Issel C.J., Montelaro R.C., Tumor necrosis factor-alpha production and disease severity after immunization with enriched major core protein (p26) and/or infection with equine infectious anemia virus, Vet. Immunol. Immunopathol. 57 (1997) 33-47.

[32] Craigo J.K., Leroux C., Howe L., Steckbeck J.D., Cook S.J., Issel C.J., Montelaro R.C., Transient immune suppression of inapparent carriers infected with a principal neutralizing domain-deficient equine infectious anaemia virus induces neutralizing antibodies and lowers steady-state virus replication, J. Gen. Virol. 83 (2002) 1353-1359.

[33] Crawford T.B., Wardrop K.J., Tornquist S.J., Reilich E., Meyers K.M., McGuire T.C., A primary production deficit in the thrombocytopenia of equine infectious anemia, J. Virol. 70 (1996) 7842-7850.

[34] Cupp E.W., Kemen M.J., The role of stable flies and mosquitoes in the transmission of equine infectious anemia virus, Proc. Annu. Meet. US Anim. Health Assoc. 84 (1980) 362-367.

[35] DeVico A.L., Issel C.J., Le Grice S.F., Payne S.L., Montelaro R.C., Sarngadharan M.G., High prevalence of serum antibodies to equine infectious anemia virus reverse transcriptase, AIDS Res. Hum. Retroviruses 9 (1993) 7-11.

[36] Dorn P.L., Derse D., Cis- and trans-acting regulation of gene expression of equine infectious anemia virus, J. Virol. 62 (1988) 3522 3526.

[37] dos Reis J.K., Melo L.M., Rezende M.R., Leite R.C., Use of an ELISA test in the eradication of an equine infectious anaemia focus, Trop. Anim. Health Prod. 26 (1994) 65-68.

[38] Dufour C., Corcione A., Svahn J., Haupt R., Poggi V., Beka'ssy A.N., Scime R., Pistorio A., Pistoia V., TNF-alpha and IFN-gamma are overexpressed in the bone marrow of Fanconi 
anemia patients and TNF-alpha suppresses erythropoiesis in vitro, Blood 102 (2003) 2053-2059.

[39] Evans D.T., O'Connor D.H., Jing P., Dzuris J.L., Sidney J., da Silva J., Allen T.M., Horton H., Venham J.E., Rudersdorf R.A., Vogel T., Pauza C.D., Bontrop R.E., DeMars R., Sette A., Hughes A.L., Watkins D.I., Virus-specific cytotoxic T-lymphocyte responses select for amino-acid variation in simian immunodeficiency virus Env and Nef, Nat. Med. 5 (1999) 1270-1276.

[40] Foil L.D., Meek C.L., Adams W.V., Issel C.J., Mechanical transmission of equine infectious anemia virus by deer flies (Chrysops flavidus) and stable flies (Stomoxys calcitrans), Am. J. Vet. Res. 44 (1983) 155-156.

[41] Foil L.D., Adams W.V., McManus J.M., Issel C.J., Bloodmeal residues on mouthparts of Tabanus fuscicostatus (Diptera: Tabanidae) and the potential for mechanical transmission of pathogens, J. Med. Entomol. 24 (1987) 613-616.

[42] Freed E.O., HIV-1 gag proteins: diverse functions in the virus life cycle, Virology 251 (1998) 1-15.

[43] Freed E.O., Viral late domains, J. Virol. 76 (2002) 4679-4687.

[44] Fujimiya Y., Perryman L.E., Crawford T.B., Leukocyte cytotoxicity in a persistent virus infection: presence of direct cytotoxicity but absence of antibody-dependent cellular cytotoxicity in horses infected with equine infectious anemia virus, Infect. Immun. 24 (1979) 628-636.

[45] Geels M.J., Cornelissen M., Schuitemaker H., Anderson K., Kwa D., Maas J., Dekker J.T., Baan E., Zorgdrager F., van den Burg R., van Beelen M., Lukashov V.V., Fu T.M., Paxton W.A., van der Hoek L., Dubey S.A., Shiver J.W., Goudsmit J., Identification of sequential viral escape mutants associated with altered T-cell responses in a human immunodeficiency virus type 1-infected individual, J. Virol. 77 (2003) 12430-12440.

[46] Gendelman H.E., Narayan O., Molineaux S., Clements J.E., Ghotbi Z., Slow, persistent replication of lentiviruses: role of tissue macrophages and macrophage precursors in bone marrow, Proc. Natl. Acad. Sci. USA 82 (1985) 7086-7090.

[47] Gendelman H.E., Narayan O., KennedyStoskopf S., Kennedy P.G., GhotbiZ., Clements J.E., Stanley J., Pezeshkpour G., Tropism of sheep lentiviruses for monocytes: susceptibility to infection and virus gene expression increase during maturation of monocytes to macrophages, J. Virol. 58 (1986) 67-74.
[48] Goldsweig H.G., Grossman R., William D., Thrombocytopenia in homosexual men, Am. J. Hematol. 21 (1986) 243-247.

[49] Gutekunst D.E., Becvar C.S., Responses in horses infected with equine infectious anemia virus adapted to tissue culture, Am. J. Vet. Res. 40 (1979) 974-977.

[50] Haase A.T., Pathogenesis of lentivirus infections, Nature 322 (1986) 130-136.

[51] Hammond S.A., Cook S.J., Lichtenstein D.L., Issel C.J., Montelaro R.C., Maturation of the cellular and humoral immune responses to persistent infection in horses by equine infectious anemia virus is a complex and lengthy process, J. Virol. 71 (1997) 3840-3852.

[52] Hammond S.A., Cook S.J., Falo L.D.J., Issel C.J., Montelaro R.C., A particulate viral protein vaccine reduces viral load and delays progression to disease in immunized ponies challenged with equine infectious anemia virus, Virology 254 (1999) 37-49.

[53] Hammond S.A., Raabe M.L., Issel C.J., Montelaro R.C., Evaluation of antibody parameters as potential correlates of protection or enhancement by experimental vaccines to equine infectious anemia virus, Virology 262 (1999) 416-430.

[54] Hammond S.A., Li F., McKeon B.M.S., Cook S.J., Issel C.J., Montelaro R.C., Immune responses and viral replication in long-term inapparent carrier ponies inoculated with equine infectious anemia virus, J. Virol. 74 (2000) 5968-5981.

[55] Harrold S.M., Cook S.J., Cook R.F., Rushlow K.E., Issel C.J., Montelaro R.C., Tissue sites of persistent infection and active replication of equine infectious anemia virus during acute disease and asymptomatic infection in experimentally infected equids, J. Virol. 74 (2000) 3112-3121.

[56] Hatanaka H., Lourin O., Rao Z., Fry E., Kingsman A., Stuart D.I., Structure of equine infectious anemia virus matrix protein, J. Virol. 76 (2002) 1876-1883.

[57] Hawkins J.A., Adams W.V., Cook L., Wilson B.H., Roth E.E., Role of horse fly (Tabanus fuscicostatus Hine) and stable fly (Stomoxys calcitrans L.) in transmission of equine infectious anemia to ponies in Louisiana, Am. J. Vet. Res. 34 (1973) 1583-1586.

[58] Hines R., Maury W., DH82 cells: a macrophage cell line for the replication and study of equine infectious anemia virus, J. Virol. Methods 95 (2001) 47-56.

[59] Hoffman D.W., White S.W., NMR analysis of the trans-activation response (TAR) RNA element of equine infectious anemia virus, Nucleic Acids Res. 23 (1995) 4058-4065. 
[60] Hoffman D.W., Colvin R.A., Garcia-Blanco M.A., White S.W., Structural features of the trans-activation response RNA element of equine infectious anemia virus, Biochemistry 32 (1993) 1096-1104.

[61] Howe L., Leroux C., Issel C.J., Montelaro R.C., Equine infectious anemia virus envelope evolution in vivo during persistent infection progressively increases resistance to in vitro serum antibody neutralization as a dominant phenotype, J. Virol. 76 (2002) 10588 10597.

[62] Hussain K.A., Issel C.J., Rwambo P.M., Arnizaut A.B., Ball J.M., Schnorr K.L., Montelaro R.C., Identification of gag precursor of equine infectious anaemia virus with monoclonal antibodies to the major viral core protein, p26, J. Gen. Virol. 69 (1988) 1719-1724.

[63] Issel C.J., Coggins L., Equine infectious anemia: current knowledge, J. Am. Vet. Med. Assoc. 174 (1979) 727-733.

[64] Issel C.J., Foil L.D., Studies on equine infectious anemia virus transmission by insects, J. Am. Vet. Med. Assoc. 184 (1984) 293-297.

[65] Issel C.J., Adams W.V.J., Meek L., Ochoa R., Transmission of equine infectious anemia virus from horses without clinical signs of disease, J. Am. Vet. Med. Assoc. 180 (1982) $272-275$

[66] Issel C.J., Horohov D.W., Lea D.F., Adams W.V.J., Hagius S.D., McManus J.M., Allison A.C., Montelaro R.C., Efficacy of inactivated whole-virus and subunit vaccines in preventing infection and disease caused by equine infectious anemia virus, J. Virol. 66 (1992) 3398-3408

[67] Karlas J.A., Siebelink K.H.,Peer M.A., Huisman W., Cuisinier A.M., Rimmelzwaan G.F., Osterhaus A.D., Vaccination with experimental feline immunodeficiency virus vaccines, based on autologous infected cells, elicits enhancement of homologous challenge infection, J. Gen. Virol. 80 (1999) 761-765.

[68] Katzmann D.J., Odorizzi G., Emr S.D., Receptor downregulation and multivesicularbody sorting, Nat. Rev. Mol. Cell Biol. 3 (2002) 893-905.

[69] Kaur A., Alexander L., Staprans S.I., Denekamp L., Hale C.L., McClure H.M., Feinberg M.B., Desrosiers R.C., Johnson R.P., Emergence of cytotoxic $\mathrm{T}$ lymphocyte escape mutations in nonpathogenic simian immunodeficiency virus infection, Eur. J. Immunol. 31 (2001) 3207-3217.

[70] Kemeny L.J., Mott L.O., Pearson J.E., Titration of equine infectious anemia virus. Effect of dosage on incubation time and clinical signs, Cornell Vet. 61 (1971) 687-695.

[71] Kettelhut I.C., Goldberg A.L., Tumor necrosis factor can induce fever in rats without acti- vating protein breakdown in muscle or lipolysis in adipose tissue, J. Clin. Invest. 81 (1988) 1384-1389.

[72] Klevjer-Anderson P., Cheevers W.P., Crawford T.B., Characterization of the infection of equine fibroblasts by equine infectious anemia virus, Arch. Virol. 60 (1979) 279-289.

[73] Knowles D. Jr., Cheevers W., McGuire T., Stem T., Gorham J., Severity of arthritis is predicted by antibody response to gp135 in chronic infection with caprine arthritisencephalitis virus, J. Virol. 64 (1990) 23962398.

[74] Kobayashi K., Kono Y., Propagation and titration of equine infectious anemia virus in horse leukocyte culture, Natl. Inst. Anim. Health Q. (Tokyo) 7 (1967) 8-20.

[75] Kono Y., Viremia and immunological responses in horses infected with equine infectious anemia virus, Natl. Inst. Anim. Health Q. (Tokyo) 9 (1969) 1-9.

[76] Kono Y., Kobayashi K., Changes in pathogenicity of equine infectious anemia virus during passages in horse leukocyte cultures, Natl. Inst. Anim. Health Q. (Tokyo) 10 (1970) $106-112$

[77] Kono Y., Yoshino T., Propagation of equine infectious anemia virus in horse kidney cell cultures, Natl. Inst. Anim. Health Q. (Tokyo) 14 (1974) 155-162.

[78] Kono Y., Kobayashi K., Fukunaga Y., Antigenic drift of equine infectious anemia virus in chronically infected horses, Arch. Gesamte Virusforsch. 41 (1973) 1-10.

[79] Kono Y., Hirasawa K., Fukunaga Y., Taniguchi $\mathrm{T}$., Recrudescence of equine infectious anemia by treatment with immunosuppressive drugs, Natl. Inst. Anim. Health Q. (Tokyo) 16 (1976) 8-15.

[80] Koup R.A., Safrit J.T., Cao Y., Andrews C.A., McLeod G., Borkowsky W., Farthing C., Ho D.D., Temporal association of cellular immune responses with the initial control of viremia in primary human immunodeficiency virus type 1 syndrome, J. Virol. 68 (1994) 4650-4655.

[81] Leroux C., Issel C.J., Montelaro R.C., Novel and dynamic evolution of equine infectious anemia virus genomic quasispecies associated with sequential disease cycles in an experimentally infected pony, J. Virol. 71 (1997) 9627-9639.

[82] Leroux C., Chastang J., Greenland T., Mornex J.F., Genomic heterogeneity of small ruminant lentiviruses: existence of heterogeneous populations in sheep and of the same lentiviral genotypes in sheep and goats, Arch. Virol. 142 (1997) 1125-1137.

[83] Leroux C., Craigo J.K., Issel C.J., Montelaro R.C., Equine infectious anemia virus genomic 
evolution in progressor and nonprogressor ponies, J. Virol. 75 (2001) 4570-4583.

[84] Lew A.M., Thomas L.M., Huntington P.J., A comparison of ELISA, FAST-ELISA and gel diffusion tests for detecting antibody to equine infectious anaemia virus, Vet. Microbiol. 34 (1993) 1-5.

[85] Li F., Puffer B.A., Montelaro R.C., The S2 gene of equine infectious anemia virus is dispensable for viral replication in vitro, J. Virol. 72 (1998) 8344-8348.

[86] Li F., Leroux C., Craigo J.K., Cook S.J., Issel C.J., Montelaro R.C., The S2 gene of equine infectious anemia virus is a highly conserved determinant of viral replication and virulence properties in experimentally infected ponies, J. Virol. 74 (2000) 573-579.

[87] Li F., Craigo J.K., Howe L., Steckbeck J.D., Cook S., Issel C., Montelaro R.C., A live attenuated equine infectious anemia virus proviral vaccine with a modified $\mathrm{S} 2$ gene provides protection from detectable infection by intravenous virulent virus challenge of experimentally inoculated horses, J. Virol. 77 (2003) 7244-7253.

[88] Liang C., Wainberg M.A., The role of Tat in HIV-1 replication: an activator and/or a suppressor? AIDS Rev. 4 (2002) 41-49.

[89] Lichtenstein D.L., Rushlow K.E., Cook R.F., Raabe M.L., Swardson C.J., Kociba G.J., Issel C.J., Montelaro R.C., Replication in vitro and in vivo of an equine infectious anemia virus mutant deficient in dUTPase activity, J. Virol. 69 (1995) 2881-2888.

[90] Lichtenstein D.L., Issel C.J., Montelaro R.C., Genomic quasispecies associated with the initiation of infection and disease in ponies experimentally infected with equine infectious anemia virus, J. Virol. 70 (1996) 33463354.

[91] Lichtenstein D.L., Craigo J.K., Leroux C., Rushlow K.E., Cook R.F., Cook S.J., Issel C.J., Montelaro R.C., Effects of long terminal repeat sequence variation on equine infectious anemia virus replication in vitro and in vivo, Virology 263 (1999) 408-417.

[92] Ligné M., Mémoire et observations sur une maladie de sang, connue sous le nom d'anhémie hydrohémie, cachexie acquise du cheval, Rec. Med. Vet. Ec. Alfort 1843 (1843) 30-44.

[93] Lloberas J., Soler C., Celada A., The key role of PU.1/SPI-1 in B cells, myeloid cells and macrophages, Immunol. Today 20 (1999) 184-189.

[94] Lonning S.M., Zhang W., Leib S.R., McGuire T.C., Detection and induction of equine infectious anemia virus-specific cytotoxic T-lymphocyte responses by use of recombinant retroviral vectors, J. Virol. 73 (1999) 2762-2769.

[95] Lonning S.M., Zhang W., McGuire T.C., Gag protein epitopes recognized by $\mathrm{CD} 4(+)$ $\mathrm{T}$-helper lymphocytes from equine infectious anemia virus-infected carrier horses, J. Virol. 73 (1999) 4257-4265.

[96] LouacheF., Bettaieb A., Henri A., Oksenhendler E., Farcet J.P., Bierling P., Seligmann M., Vainchenker W., Infection of megakaryocytes by human immunodeficiency virus in seropositive patients with immune thrombocytopenic purpura, Blood 78 (1991) $1697-$ 1705.

[97] Louache F., Henri A., Bettaieb A., Oksenhendler E., Raguin G., Tulliez M., Vainchenker W., Role of human immunodeficiency virus replication in defective in vitro growth of hematopoietic progenitors, Blood 80 (1992) 29912999.

[98] Madden C.R., Shih D.S., Analysis of the long terminal repeat from a cytopathic strain of equine infectious anemia virus, Virology 225 (1996) 395-399.

[99] Malmquist W.A., Barnett D., Becvar C.S., Production of equine infectious anemia antigen in a persistently infected cell line, Arch. Gesamte Virusforsch. 42 (1973) 361-370.

[100] Martarano L., Stephens R., Rice N., Derse D., Equine infectious anemia virus trans-regulatory protein Rev controls viral mRNA stability, accumulation, and alternative splicing, J. Virol. 68 (1994) 3102-3111.

[101] Martin-Serrano J., Yaravoy A., Perez-Caballero D., Bieniasz P.D., Divergent retroviral latebudding domains recruit vacuolar protein sorting factors by using alternative adaptor proteins, Proc. Natl. Acad. Sci. USA 100 (2003) 12414-12419.

[102] Maury W., Monocyte maturation controls expression of equine infectious anemia virus, J. Virol. 68 (1994) 6270-6279.

[103] Maury W., Perryman S., Oaks J.L., Seid B.K., Crawford T., McGuire T., Carpenter S., Localized sequence heterogeneity in the long terminal repeats of in vivo isolates of equine infectious anemia virus, J. Virol. 71 (1997) 4929-4937.

[104] Maury W., Oaks J.L., Bradley S., Equine endothelial cells support productive infection of equine infectious anemia virus, J. Virol. 72 (1998) 9291-9297.

[105] Maury W., Bradley S., Wright B., Hines R., Cell specificity of the transcription-factor repertoire used by a lentivirus: motifs important for expression of equine infectious anemia virus in nonmonocytic cells, Virology 267 (2000) 267-278. 
[106] Maury W., Wright P.J., Bradley S., Characterization of a cytolytic strain of equine infectious anemia virus, J. Virol. 77 (2003) 23852399.

[107] McGuire T.C., Crawford T.B., Henson J.B., Immunofluorescent localization of equine infectious anemia virus in tissue, Am. J. Pathol. 62 (1971) 283-294.

[108] McGuire T.C., Banks K.L., Poppie M.J., Combined immunodeficiency in horses: characterization of the lymphocyte defect, Clin. Immunol. Immunopathol. 3 (1975) 555-566.

[109] McGuire T.C., Adams D.S., Johnson G.C., Klevjer-Anderson P., Barbee D.D., Gorham J.R., Acute arthritis in caprine arthritisencephalitis virus challenge exposure of vaccinated or persistently infected goats, Am. J. Vet. Res. 47 (1986) 537-540.

[110] McGuire T.C., Tumas D.B., Byrne K.M., Hines M.T., Leib S.R., Brassfield A.L., O'Rourke K.I., Perryman L.E., Major histocompatibility complex-restricted $\mathrm{CD}^{+}$cytotoxic $\mathrm{T}$ lymphocytes from horses with equine infectious anemia virus recognize Env and Gag/PR proteins, J. Virol. 68 (1994) 1459_ 1467.

[111] McGuire T.C., Zhang W., Hines M.T., Henney P.J., Byrne K.M., Frequency of memory cytotoxic T lymphocytes to equine infectious anemia virus proteins in blood from carrier horses, Virology 238 (1997) 85-93.

[112] McGuire T.C., Fraser D.G., Mealey R.H., Cytotoxic $\mathrm{T}$ lymphocytes and neutralizing antibody in the control of equine infectious anemia virus, Viral Immunol. 15 (2002) 521531.

[113] Mealey R.H., Fraser D.G., Oaks J.L., Cantor G.H., McGuire T.C., Immune reconstitution prevents continuous equine infectious anemia virus replication in an arabian foal with severe combined immunodeficiency: lessons for control of lentiviruses, Clin. Immunol. 101 (2001) 237-247.

[114] Mealey R.H., Zhang B., Leib S.R., Littke M.H., McGuire T.C., Epitope specificity is critical for high and moderate avidity cytotoxic T lymphocytes associated with control of viral load and clinical disease in horses with equine infectious anemia virus, Virology 313 (2003) 537-552.

[115] Mellors J.W., Rinaldo C.R. Jr., Gupta P., White R.M., Todd J.A., Kingsley L.A., Prognosis in HIV-1 infection predicted by the quantity of virus in plasma, Science 272 (1996) 1167-1170.

[116] Moldawer L.L., Marano M.A., Wei H., Fong Y., Silen M.L., Kuo G., Manogue K.R., Vlassara H., Cohen H., Cerami A., et al., Cachectin/tumor necrosis factor-alpha alters red blood cell kinetics and induces anemia in vivo, Faseb J. 3 (1989) 1637-1643.

[117] Montelaro R.C., Parekh B., Orrego A., Issel C.J., Antigenic variation during persistent infection by equine infectious anemia virus, a retrovirus, J. Biol. Chem. 259 (1984) 10539-10544.

[118] Montelaro R.C., Cole K.S., Hammond S.A., Maturation of immune responses to lentivirus infection: implications for AIDS vaccine development, AIDS Res. Hum. Retroviruses 14 Suppl. 3 (1998) S255-259.

[119] Moore C.B., John M., James I.R., Christiansen F.T., Witt C.S., Mallal S.A., Evidence of HIV-1 adaptation to HLA-restricted immune responses at a population level, Science 296 (2002) 1439-1443.

[120] Narayan O., Kennedy-Stoskopf S., Sheffer D., Griffin D.E., Clements J.E., Activation of caprine arthritis-encephalitis virus expression during maturation of monocytes to macrophages, Infect. Immun. 41 (1983) 67-73.

[121] Nishimura Y., Igarashi T., Haigwood N., Sadjadpour R., Plishka R.J., Buckler-White A., Shibata R., Martin M.A., Determination of a statistically valid neutralization titer in plasma that confers protection against simian-human immunodeficiency virus challenge following passive transfer of hightitered neutralizing antibodies, J. Virol. 76 (2002) 2123-2130.

[122] Noiman S., Yaniv A., Sherman L., Tronick S.R., Gazit A., Pattern of transcription of the genome of equine infectious anemia virus, $\mathrm{J}$. Virol. 64 (1990) 1839-1843.

[123] O'Rourke K., Perryman L.E., McGuire T.C. Antiviral, anti-glycoprotein and neutralizing antibodies in foals with equine infectious anaemia virus, J. Gen. Virol. 69 (1988) 667674.

[124] Oaks J.L., McGuire T.C., Ulibarri C., Crawford T.B., Equine infectious anemia virus is found in tissue macrophages during subclinical infection, J. Virol. 72 (1998) 7263-7269.

[125] Oaks J.L., Ulibarri C., Crawford T.B., Endothelial cell infection in vivo by equine infectious anaemia virus, J. Gen. Virol. 80 (1999) 2393 2397.

[126] Orrego A., Issel C.J., Montelaro R.C., Adams W.V.J., Virulence and in vitro growth of a cell-adapted strain of equine infectious anemia virus after serial passage in ponies, Am J. Vet. Res. 43 (1982) 1556-1560.

[127] Parent L.J., Bennett R.P., Craven R.C., Nelle T.D., Krishna N.K., Bowzard J.B., Wilson C.B., Puffer B.A., Montelaro R.C., Wills J.W., Positionally independent and exchangeable late budding functions of the Rous sarcoma virus and human immunodeficiency 
virus Gag proteins, J. Virol. 69 (1995) 54555460.

[128] Payne S.L., Rausch J., Rushlow K., Montelaro R.C., Issel C., Flaherty M., Perry S., Sellon D., Fuller F., Characterization of infectious molecular clones of equine infectious anaemia virus, J. Gen. Virol. 75 (1994) 425-429.

[129] Payne S.L., Qi X.M., Shao H., Dwyer A., Fuller F.J., Disease induction by virus derived from molecular clones of equine infectious anemia virus, J. Virol. 72 (1998) 483-487.

[130] Pearson J.E., Gipson C.A., Standardization of equine infectious anemia immunodiffusion and cELISA tests and their application to control of the disease in the United States, Equine Vet. Science 8 (1988) 60-61.

[131] Pedersen N.C., Johnson L., Birch D., Theilen G.H., Possible immunoenhancement of persistent viremia by feline leukemia virus envelope glycoprotein vaccines in challengeexposure situations where whole inactivated virus vaccines were protective, Vet. Immunol. Immunopathol. 11 (1986) 123-148.

[132] Peluso R., Haase A., Stowring L., Edwards M., Ventura P., A Trojan Horse mechanism for the spread of visna virus in monocytes, Virology 147 (1985) 231-236.

[133] Perryman L.E., O'Rourke K.I., McGuire T.C., Immune responses are required to terminate viremia in equine infectious anemia lentivirus infection, J. Virol. 62 (1988) 3073 3076.

[134] Preston B.D., Poiesz B.J., Loeb L.A., Fidelity of HIV-1 reverse transcriptase, Science 242 (1988) 1168-1171.

[135] Puffer B.A., Parent L.J., Wills J.W., Montelaro R.C., Equine infectious anemia virus utilizes a YXXL motif within the late assembly domain of the Gag p9 protein, J. Virol. 71 (1997) 6541-6546.

[136] Puffer B.A., Watkins S.C., Montelaro R.C., Equine infectious anemia virus Gag polyprotein late domain specifically recruits cellular AP-2 adapter protein complexes during virion assembly, J. Virol. 72 (1998) 10218 10221.

[137] Raabe M.R., Issel C.J., Montelaro R.C., Equine monocyte-derived macrophage cultures and their applications for infectivity and neutralization studies of equine infectious anemia virus, J. Virol. Methods 71 (1998) 87-104.

[138] Raabe M.L., Issel C.J., Cook S.J., Cook R.F., Woodson B., Montelaro R.C., Immunization with a recombinant envelope protein (rgp90) of EIAV produces a spectrum of vaccine efficacy ranging from lack of clinical disease to severe enhancement, Virology 245 (1998) 151-162.

[139] Raabe M.L., Issel C.J., Montelaro R.C., In vitro antibody-dependent enhancement assays are insensitive indicators of in vivo vaccine enhancement of equine infectious anemia virus, Virology 259 (1999) 416-427.

[140] Rasty S., Dhruva B.R., Schiltz R.L., Shih D.S., Issel C.J., Montelaro R.C., Proviral DNA integration and transcriptional patterns of equine infectious anemia virus during persistent and cytopathic infections, J. Virol. 64 (1990) 86-95.

[141] Reed-Inderbitzin E., Maury W., Cellular specificity of HIV-1 replication can be controlled by LTR sequences, Virology 314 (2003) 680-695.

[142] Reis J.K., Craigo J.K., Cook S.J., Issel C.J., Montelaro R.C., Characterization of EIAV LTR variability and compartmentalization in various reservoir tissues of long-term inapparent carrier ponies, Virology 311 (2003) 169-180.

[143] Rice N.R., Lequarre A.S., Casey J.W., Lahn S., Stephens R.M., Edwards J., Viral DNA in horses infected with equine infectious anemia virus, J. Virol. 63 (1989) 5194-5200.

[144] Richardson J., Broche S., Baud S., LesteLasserre T., Femenia F., Levy D., Moraillon A., Pancino G., Sonigo P., Lymphoid activation: a confounding factor in AIDS vaccine development? J. Gen. Virol. 83 (2002) 25152521.

[145] Ridgely S.L., McGuire T.C., Lipopeptide stimulation of MHC class I-restricted memory cytotoxic $\mathrm{T}$ lymphocytes from equine infectious anemia virus-infected horses, Vaccine 20 (2002) 1809-1819.

[146] Ridgely S.L., Zhang B., McGuire T.C., Response of ELA-A1 horses immunized with lipopeptide containing an equine infectious anemia virus ELA-A1-restricted CTL epitope to virus challenge, Vaccine 21 (2003) 491-506.

[147] Roberts J.D., Bebenek K., Kunkel T.A., The accuracy of reverse transcriptase from HIV-1, Science 242 (1988) 1171-1173.

[148] Robertson D.L., Hahn B.H., Sharp P.M., Recombination in AIDS viruses, J. Mol. Evol. 40 (1995) 249-259.

[149] Rous P., A sarcoma of the fowl transmissible by an agent separable from the tumor cells, J. Exp. Med. 13 (1911) 397-411.

[150] Rwambo P.M., Issel C.J., Adams W.V. Jr., Hussain K.A., Miller M., Montelaro R.C., Equine infectious anemia virus (EIAV) humoral responses of recipient ponies and antigenic variation during persistent infection, Arch. Virol. 111 (1990) 199-212. 
[151] Salguero F.J., Ruiz-Villamor E., Bautista M.J., Sanchez-Cordon P.J., Carrasco L., Gomez-Villamandos J.C., Changes in macrophages in spleen and lymph nodes during acute African swine fever: expression of cytokines, Vet. Immunol. Immunopathol. 90 (2002) 11-22.

[152] Salinovich O., Payne S.L., Montelaro R.C., Hussain K.A., Issel C.J., Schnorr K.L., Rapid emergence of novel antigenic and genetic variants of equine infectious anemia virus during persistent infection, J. Virol. 57 (1986) 71-80.

[153] Schiltz R.L., Shih D.S., Rasty S., Montelaro R.C., Rushlow K.E., Equine infectious anemia virus gene expression: characterization of the RNA splicing pattern and the protein products encoded by open reading frames $\mathrm{S} 1$ and S2, J. Virol. 66 (1992) 3455-3465.

[154] Sellon D.C., Perry S.T., Coggins L., Fuller F.J., Wild-type equine infectious anemia virus replicates in vivo predominantly in tissue macrophages, not in peripheral blood monocytes, J. Virol. 66 (1992) 5906-5913.

[155] Sellon D.C., Fuller F.J., McGuire T.C., The immunopathogenesis of equine infectious anemia virus, Virus Res. 32 (1994) 111-138.

[156] Sentsui H., Kono Y., Complement-mediated hemolysis of horse erythrocytes treated with equine infectious anemia virus, Arch. Virol. 95 (1987) 53-66.

[157] Shen R., Wang Z.M., Development and use of an equine infectious aneamia donkey leukocyte attenuated vaccine, in: Tashjian R. (Ed.), Equine Infectious Anemia: a national review of policies, programs, and future objectives, Amarillo, Texas, 1985, pp. 135148.

[158] Sherman L., Gazit A., Yaniv A., Kawakami T., Dahlberg J.E., Tronick S.R., Localization of sequences responsible for trans-activation of the equine infectious anemia virus long terminal repeat, J. Virol. 62 (1988) 120-126.

[159] Shibata R., Igarashi T., Haigwood N., BucklerWhite A., Ogert R., Ross W., Willey R., Cho M.W., Martin M.A., Neutralizing antibody directed against the HIV-1 envelope glycoprotein can completely block HIV-1/SIV chimeric virus infections of macaque monkeys, Nat. Med. 5 (1999) 204-210.

[160] Soutullo A., Verwimp V., Riveros M., Pauli R., Tonarelli G., Design and validation of an ELISA for equine infectious anemia (EIA) diagnosis using synthetic peptides, Vet. Microbiol. 79 (2001) 111-121.

[161] Spyrou V., Papanastassopoulou M., Psychas V., Billinis C., Koumbati M., Vlemmas J., Koptopoulos G., Equine infectious anemia in mules: virus isolation and pathogenicity studies, Vet. Microbiol. 95 (2003) 49-59.
[162] Steagall W.K., Robek M.D., Perry S.T., Fuller F.J., Payne S.L., Incorporation of uracil into viral DNA correlates with reduced replication of EIAV in macrophages, Virology 210 (1995) 302-313.

[163] Stephens R.M., Casey J.W., Rice N.R., Equine infectious anemia virus $g a g$ and $p o l$ genes: relatedness to visna and AIDS virus, Science 231 (1986) 589-594.

[164] Stephens R.M., Derse D., Rice N.R., Cloning and characterization of cDNAs encoding equine infectious anemia virus tat and putative Rev proteins, J. Virol. 64 (1990) 3716 3725.

[165] Sticht H., Willbold D., Bayer P., Ejchart A., Herrmann F., Rosin-Arbesfeld R., Gazit A., Yaniv A., Frank R., Rosch P., Equine infectious anemia virus Tat is a predominantly helical protein, Eur. J. Biochem. 218 (1993) 973-976.

[166] Strack B., Calistri A., Craig S., Popova E., Gottlinger H.G., AIP1/ALIX is a binding partner for HIV-1 p6 and EIAV p9 functioning in virus budding, Cell 114 (2003) 689699.

[167] Sune C., Goldstrohm A.C., Peng J., Price D.H., Garcia-Blanco M.A., An in vitro transcription system that recapitulates equine infectious anemia virus tat-mediated inhibition of human immunodeficiency virus type 1 Tat activity demonstrates a role for positive transcription elongation factor $b$ and associated proteins in the mechanism of Tat activation, Virology 274 (2000) 356-366.

[168] Swanstrom R., Wills J.W., Synthesis, assembly, and processing of viral proteins, in: Coffin J.M., Hughes S.H., Varmus H.E. (Eds.), Retroviruses, Cold Spring Harbor Laboratory Press, Cold Spring Harbor, New York, 1997, pp. 263-334.

[169] Takada A., Kawaoka Y., Antibody-dependent enhancement of viral infection: molecular mechanisms and in vivo implications, Rev. Med. Virol. 13 (2003) 387-398.

[170] Tanzi G.O., Piefer A.J., Bates P., Equine infectious anemia virus utilizes host vesicular protein sorting machinery during particle release, J. Virol. 77 (2003) 8440-8447.

[171] Ten Haaft P., Verstrepen B., Uberla K., Rosenwirth B., Heeney J., A pathogenic threshold of virus load defined in simian immunodeficiency virus- or simian-human immunodeficiency virus-infected macaques, J. Virol. 72 (1998) 10281-10285.

[172] Tencza S.B., Islam K.R., Kalia V., Nasir M.S., Jolley M.E., Montelaro R.C., Development of a fluorescence polarization-based diagnostic assay for equine infectious anemia virus, J. Clin. Microbiol. 38 (2000) 18541859. 
[173] Thomas D.A., Furman P.A., Purification and kinetic characterization of equine infectious anemia virus reverse transcriptase, Biochem. Biophys. Res. Commun. 180 (1991) 13651371.

[174] Threadgill D.S., Steagall W.K., Flaherty M.T., Fuller F.J., Perry S.T., Rushlow K.E., Le Grice S.F., Payne S.L., Characterization of equine infectious anemia virus dUTPase: growth properties of a dUTPase-deficient mutant, J. Virol. 67 (1993) 2592-2600.

[175] Tornquist S.J., Oaks J.L., Crawford T.B., Elevation of cytokines associated with the thrombocytopenia of equine infectious anaemia, J. Gen. Virol. 78 (1997) 2541-2548.

[176] Tschetter J.R., Byrne K.M., Perryman L.E., McGuire T.C., Control of equine infectious anemia virus is not dependent on ADCC mediating antibodies, Virology 230 (1997) 275-280.

[177] Tumas D.B., Hines M.T., Perryman L.E., Davis W.C., McGuire T.C., Corticosteroid immunosuppression and monoclonal antibody-mediated $\mathrm{CD}^{+} \mathrm{T}$ lymphocyte depletion in normal and equine infectious anaemia virus-carrier horses, J. Gen. Virol. 75 (1994) 959-968.

[178] Vallée H., Carré H., Sur la nature infectieuse de l'anémie du cheval, C. R. Acad. Sci. 139 (1904) 331-333.

[179] Van Regenmortel M.H., Mayo M.A., Fauquet C.M., Maniloff J., Virus nomenclature: consensus versus chaos, Arch. Virol. 145 (2000) 2227-2232.

[180] Villet S., Bouzar B.A., Morin T., Verdier G., Legras C., Chebloune Y., Maedi-visna virus and caprine arthritis encephalitis virus genomes encode a Vpr-like but no Tat protein, J. Virol. 77 (2003) 9632-9638.

[181] Villet S., Faure C., Bouzar B.A., Morin T., Verdier G., Chebloune Y., Legras C., Lack of trans-activation function for Maedi-visna virus and Caprine arthritis encephalitis virus Tat proteins, Virology 307 (2003) 317-327.

[182] Von Schwedler U.K., Stuchell M., Muller B., Ward D.M., Chung H.Y., Morita E., Wang H.E., Davis T., He G.P., Cimbora D.M., Scott A., Krausslich H.G., Kaplan J., Morham S.G., Sundquist W.I., The protein network of HIV budding, Cell 114 (2003) 701-713.

[183] Wang S.Z., Rushlow K.E., Issel C.J., Cook R.F., Cook S.J., Raabe M.L., Chong Y.H., Costa L., Montelaro R.C., Enhancement of EIAV replication and disease by immunization with a baculovirus-expressed recombinant envelope surface glycoprotein, Virology 199 (1994) 247-251.

[184] Whetter L., Archambault D., Perry S., Gazit A., Coggins L., Yaniv A., Clabough D., Dahlberg J., Fuller F., Tronick S., Equine infectious anemia virus derived from a molecular clone persistently infects horses, J. Virol. 64 (1990) 5750-5756.

[185] Willbold D., Rosin-Arbesfeld R., Sticht H., Frank R., Rosch P., Structure of the equine infectious anemia virus Tat protein, Science 264 (1994) 1584-1587.

[186] Yoon S., Kingsman S.M., Kingsman A.J., Wilson S.A., Mitrophanous K.A., Characterization of the equine infectious anaemia virus S2 protein, J. Gen. Virol. 81 (2000) 21892194.

[187] Zauli G., Re M.C., Davis B., Sen L., Visani G., Gugliotta L., Furlini G., La Placa M., Impaired in vitro growth of purified $\left(\mathrm{CD} 34^{+}\right)$ hematopoietic progenitors in human immunodeficiency virus-1 seropositive thrombocytopenic individuals, Blood 79 (1992) 26802687.

[188] Zhang W., Lonning S.M., McGuire T.C., Gag protein epitopes recognized by ELA-Arestricted cytotoxic $\mathrm{T}$ lymphocytes from horses with long-term equine infectious anemia virus infection, J. Virol. 72 (1998) 96129620.

[189] Zhang W., Auyong D.B., Oaks J.L., McGuire T.C., Natural variation of equine infectious anemia virus Gag protein cytotoxic $\mathrm{T}$ lymphocyte epitopes, Virology 261 (1999) 242 252.

[190] Zheng Y.H., Nakaya T., Sentsui H., Kameoka M., Kishi M., Hagiwara K., Takahashi H., Kono Y., Ikuta K., Insertions, duplications and substitutions in restricted gp90 regions of equine infectious anaemia virus during febrile episodes in an experimentally infected horse, J. Gen. Virol. 78 (1997) 807-820.

[191] Zheng Y.H., Sentsui H., Kono Y., Ikuta K., Mutations occurring during serial passage of Japanese equine infectious anemia virus in primary horse macrophages, Virus Res. 68 (2000) 93-98.

[192]Zientara S., L'anémie infectieuse des équidés: déjà 3 foyers en 1999, Bull. G.T.V. 1 (1999) 39-40.

[193]Zientara S., L'anémie infectieuse des équidés: la situation épidémiologique en France depuis 1993, Bull. G.T.V. 1 (1999) 41-43.

[194] Zucker-Franklin D., Cao Y.Z., Megakaryocytes of human immunodeficiency virusinfected individuals express viral RNA, Proc. Natl. Acad. Sci. USA 86 (1989) 5595-5599.

[195]Zucker-Franklin D., Seremetis S., Zheng Z.Y., Internalization of human immunodeficiency virus type I and other retroviruses by megakaryocytes and platelets, Blood 75 (1990) 1920-1923. 